\title{
Late Quaternary environmental and landscape dynamics revealed by a pingo sequence on the northern Seward Peninsula, Alaska
}

\author{
Sebastian Wetterich ${ }^{\mathrm{a}, *}$, Guido Grosse ${ }^{\mathrm{b}}$, Lutz Schirrmeister ${ }^{\mathrm{a}}$, Andrei A. Andreev ${ }^{\mathrm{c}}$, Anatoly A. Bobrov ${ }^{\mathrm{d}}$, \\ Frank Kienast ${ }^{\mathrm{e}}$, Nancy H. Bigelow ${ }^{\mathrm{f}}$, Mary E. Edwards ${ }^{\mathrm{f}, \mathrm{g}}$ \\ a Department of Periglacial Research, Alfred Wegener Institute for Polar and Marine Research, Potsdam, Germany \\ ${ }^{\mathrm{b}}$ Geophysical Institute, University of Alaska Fairbanks, USA \\ ${ }^{\mathrm{c}}$ Institute of Geology and Mineralogy, University of Cologne, Germany \\ ${ }^{\mathrm{d}}$ Faculty of Soil Science, Moscow State University, Russia \\ e Senckenberg Research Institute and Natural History Museum, Research Station for Quaternary Palaeontology, Weimar, Germany \\ ${ }^{\mathrm{f}}$ Alaska Quaternary Center, University of Alaska Fairbanks, USA \\ ${ }^{\mathrm{g}}$ Geography and Environment, University of Southampton, UK
}

\section{A R T I C L E I N F O}

\section{Article history:}

Received 26 September 2011

Received in revised form

26 January 2012

Accepted 30 January 2012

Available online $\mathrm{xxx}$

Keywords:

Holocene Thermal Maximum

Central Beringia

Thermokarst

Pingo

Spruce

Picea sp.

\begin{abstract}
A B S T R A C T
A terrestrial sediment sequence exposed in an eroding pingo provides insights into the late-Quaternary environmental history of the northern Seward Peninsula, Alaska. We have obtained the first radiocarbondated evidence for a mid-Wisconsin thermokarst lake, demonstrating that complex landscape dynamics involving cyclic permafrost aggradation and thermokarst lake formation occurred over stadialinterstadial as well as glacial-interglacial time periods. High values of Picea pollen and the presence of Larix pollen in sediments dated to 50-40 ka BP strongly suggest the presence of forest or woodland early in MIS 3; the trees grew within a vegetation matrix dominated by grass and sedge, and there is indirect evidence of grazing animals. Thus the interstadial ecosystem was different in structure and composition from the Holocene or from the preceding Last Interglacial period. An early Holocene warm period is indicated by renewed thermokarst lake formation and a range of fossil taxa. Multiple extralimital plant taxa suggest mean July temperatures above modern values. The local presence of spruce during the early Holocene warm interval is evident from a radiocarbon-dated spruce macrofossil remain and indicates significant range extension far beyond the modern tree line. The first direct evidence of spruce in Northwest Alaska during the early Holocene has implications for the presence of forest refugia in Central Beringia and previously assumed routes and timing of post-glacial forest expansion in Alaska.
\end{abstract}

(c) 2012 Elsevier Ltd. All rights reserved.

\section{Introduction}

During sea-level low stands in late-Quaternary glacial periods, the shallow Arctic shelves between Siberia and North America formed an extensive landmass (Beringia) that encompassed several million square kilometres of low mountain regions, lowlands and exposed shelf plains (Hultén, 1937; Hopkins, 1967, 1982). Environmental characteristics of this region during the last glacial, such as high continentality, low overall precipitation, severe cold winters resulted in a unique cold-climate ecosystem with no exact modern analogue. At such times, central Beringia served as a bridge between the ecosystems of Eurasia and America and a barrier between the

\footnotetext{
* Corresponding author.

E-mail address: sebastian.wetterich@awi.de (S. Wetterich).
}

Arctic and Pacific oceans. During interglacial periods, partial inundation from sea level rise, plus climatically driven northward and westward advance of boreal forest and establishment of moist tundra vegetation virtually eliminated the glacial ecosystem (Hopkins, 1973). Despite the repeated near disappearance of glacial and interglacial ecosystems through time, various authors argue for the existence of refugia that allowed survival of faunal and floral components of these ecosystems during unfavourable periods and served as starting points for the renewed expansion of such species in favourable periods (Hultén, 1937; Hopkins et al., 1981; Yurtsev, 1982; Edwards and Armbruster, 1989; Brubaker et al., 2005). The Bering Land Bridge region therefore has a key role for our understanding of late-Quaternary ecosystem and climate dynamics in the northern hemisphere, the dynamics of species migration in a geographically changing environment, as well as the peopling of America (Hopkins, 1959a, 1967, 1982; Hopkins et al., 1965; Elias 
et al., 1996; Brigham-Grette, 2001). Records of the Beringian palaeoenvironment are preserved in permafrost and lacustrine deposits in Arctic lowlands and hills and inundated terrestrial continental shelf deposits of Northeast Siberia, Alaska and Northwest Canada (e.g. Elias et al., 1996, 1997; Brigham-Grette, 2001), including regions in Central Beringia such as the Seward Peninsula in NW Alaska.

Palaeoenvironmental proxies from permafrost deposits are valuable tools with which to reconstruct past climates and ecosystems for regions where other archives, such as long ice-core or lake-sediment records, are either rare or absent. Due to cold climatic conditions throughout the late Quaternary in the vast unglaciated territory between the Eurasian and the Laurentide ice sheets, permafrost formed, persisted and preserved fossil remains of faunal, floral and microbial communities in good to excellent condition; characteristics of ground ice and sediments are also well preserved. Therefore, permafrost deposits are increasingly used as an archive of late-Quaternary environmental and climatic conditions in the high latitudes of the northern hemisphere (e.g. Matthews, 1974a; McDowell and Edwards, 2001; Murton, 2001; Schirrmeister et al., 2002, 2008; Muhs et al., 2003; Hubberten et al., 2004; Sher et al., 2005; Froese et al., 2008; Kienast et al., 2008; Kuzmina et al., 2008; Wetterich et al., 2008; Meyer et al., 2010; Andreev et al., 2011).

Several palaeoenvironmental records from the Seward Peninsula that cover large parts of the late Quaternary were produced in previous decades from the Imuruk Lake region (Hopkins, 1959b, 1963; Colinvaux, 1964; McCulloch and Hopkins, 1966) and the Kotzebue Sound region (McCulloch and Hopkins, 1966; Matthews, 1974a; Hopkins et al., 1976; Jordan and Mason, 1999). Some studies focused on specific important palaeoenvironmental indicators, such as fossil soil properties (Höfle and Ping, 1996; Höfle et al., 2000), pollen (Colinvaux, 1964), plant macrofossils (Goetcheus et al., 1994; Goetcheus and Birks, 2001), insects (Elias, 2000, 2001; Kuzmina et al., 2008), and tephra (Begét et al., 1992, 1996). Many studies in the northern Seward Peninsula are focussed on a prominent palaeosol, the Kitluk palaeosol, an ancient land surface buried and preserved by a ca $1-\mathrm{m}$ thick tephra layer from the Devil Mountain Maar eruption. The soil is radiocarbon-dated to $21.5 \mathrm{ka}$ cal BP (Begét et al., 1996) and thus is representative of conditions during the Last Glacial Maximum (LGM).

In this paper we present a multi-proxy palaeoenvironmental study covering the mid-Wisconsin to Holocene period based on sedimentological, geocryological, and palaeontological (pollen, plant macrofossils, ostracods, testate amoebae) data from a different element of the periglacial landscape, an eroding pingo exposed in the coastal cliffs of the northern Seward Peninsula.

\section{Study site}

\subsection{Pingo}

The studied exposure is part of a pingo situated on the northern coast of the Seward Peninsula and currently breached by coastal erosion; it lies close to the mouth of the Kitluk River at $66^{\circ} 34^{\prime} 58^{\prime \prime} \mathrm{N}$ and $164^{\circ} 18^{\prime} 25^{\prime \prime} \mathrm{W}$ (Figs. 1 and 2). In summer 2008, the maximal height of the pingo remnant was about $18 \mathrm{~m}$ above sea level (a.s.l.) and $8.5 \mathrm{~m}$ above the surrounding basin. The largest diameter of the pingo remnant reached about $130 \mathrm{~m}$, and the mean slope was $7.7^{\circ}$ ranging between minimum and maximum values of $0.7^{\circ}$ and $22.9^{\circ}$, respectively. The pingo ice core was not exposed.

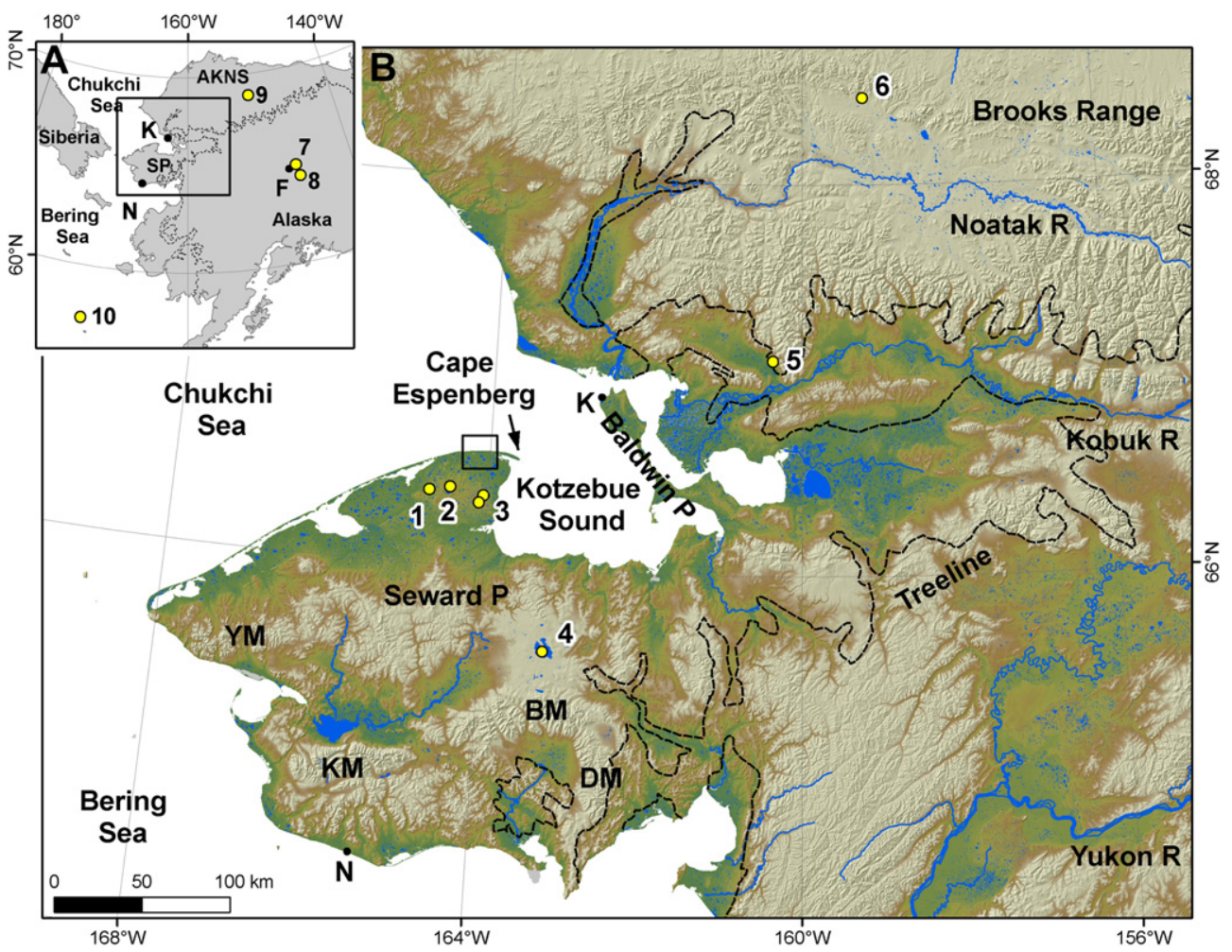

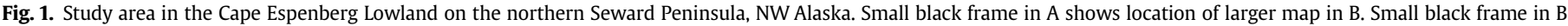

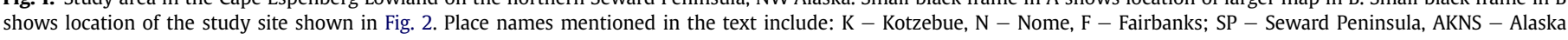

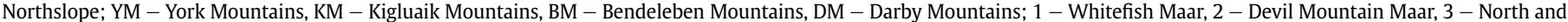

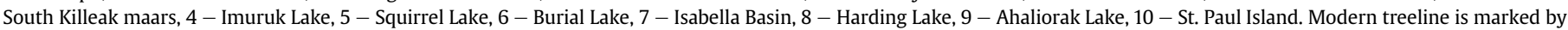
dashed black line in both maps (from Circumpolar Arctic Vegetation Map, Walker et al., 2005). 


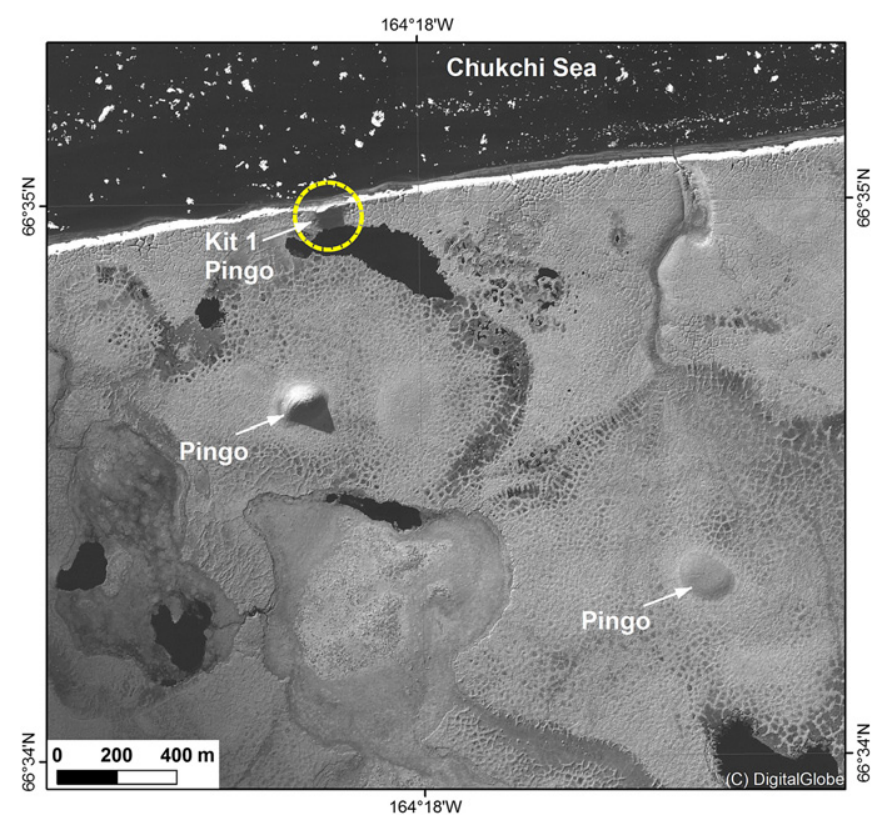

Fig. 2. High-resolution, panchromatic Quickbird satellite image (DigitalGlobe) of the study site west of the Kitluk River at the northern coast of Seward Peninsula, Alaska from 16 June 2002. White arrows indicate location of other pingos within adjacent thermokarst basins.

Hydrostatic (closed system) pingos like the studied one are common features in circum-arctic lowlands with continuous permafrost (e.g. Mackay, 1962; Grosse and Jones, 2011; Jones et al., 2012). Pingos are defined as perennial frost mounds consisting of a core of massive ice, produced primarily by injection of water, and covered with soil and vegetation (van Everdingen, 1998). The formation and presence of pingos is closely linked to past and present local climatological, geological, and hydrological conditions. Pingo growth and decay rates, pingo age, and past distribution of pingos have been used for palaeoenvironmental reconstructions in periglacial landscapes (Flemal, 1976; Mackay, 1986; Walker et al., 1996). In addition, sediments in pingos have also been used for palaeoenvironmental reconstructions (Hyvärinen and Ritchie, 1975; Grosse et al., 2007).

Hydrostatic pingos form in drained thermokarst lake basins when pressurised water in the refreezing zone (talik) under the former lake migrates towards a common freezing front and accumulates in a growing ice core (Mackay, 1985). The formation of such a massive ground ice body induces an up-doming of overlying frozen sediments and the terrain surface resulting in conical, domelike mounds of elliptical to circular planar shape with diameters of up to several hundred meters and heights of up to several dozen meters (van Everdingen, 1998). The up-doming of sediment overlying the ice core provides access to sediments that otherwise are located much deeper and would be more difficult to sample.

\subsection{Environment}

The modern climate conditions on the Seward Peninsula are typical for the Subarctic and characterised by long, cold winters and short, cool summers (Hammond and Yarie, 1996). However, the current climate is heterogeneous across the Seward Peninsula and follows spatial and temporal patterns related to latitude, elevation and coastal effects (Manley and Daly, 2005). The widely dispersed weather stations in northwest Alaska mean that data are lacking to portray these differences. The closest station with long-term records is Kotzebue at a distance of ca $95 \mathrm{~km}$ to the NE across the open sea of the Kotzebue Sound (Fig. 1). Mean annual air temperature (MAAT) at that station is $-5.7{ }^{\circ} \mathrm{C}$ for $1971-2000$ (Alaska Climate Research Center, 2008). Average air temperatures for January $\left(T_{\text {Jan }}\right)$ and July $\left(T_{\text {July }}\right)$ are about $-19.2{ }^{\circ} \mathrm{C}$ and $12.6{ }^{\circ} \mathrm{C}$ respectively. Mean annual precipitation (MAP) amounts to about $254 \mathrm{~mm}$. Based on climate data from the high-resolution gridded parameter-elevation regressions on independent slopes model (PRISM) for Alaska (Manley and Daly, 2005), the northern portion of the Seward Peninsula, including our study area, differs slightly from the Kotzebue record. Our study area is inferred to have somewhat milder MAAT $\left(-5^{\circ} \mathrm{C}\right)$ and $T_{\text {Jan }}\left(-17^{\circ} \mathrm{C}\right)$, a slightly cooler $T_{\text {July }}\left(11^{\circ} \mathrm{C}\right)$, and lower MAP $(<200 \mathrm{~mm})$.

In general, the growing season from May to September is cool and wet along the coast, but warmer and drier conditions prevail further inland (Rupp et al., 2001). The Seward Peninsula is underlain by discontinuous permafrost in its southern part and by continuous permafrost in its northern part, where permafrost thickness reaches more than $90 \mathrm{~m}$ (Hopkins et al., 1955; Jorgenson et al., 2008).

During the Pleistocene, the Seward Peninsula was repeatedly glaciated in the southern and western parts around the York, Kigluaik, Bendeleben, and Darby Mountains (Fig. 1; Kaufman and Hopkins, 1986; Calkin et al., 1998; Kaufman and Manley, 2004), whereas the northern lowland plains were dominated by deposition of loess-like deposits originating from the floodplains of the palaeoriver that combined the modern Noatak and Kobuk rivers on the then exposed shelf (Pewé, 1975). The deposition resulted in syngenetic permafrost formation with large ice wedges and high excess ground ice content similar to other Yedoma sites in Alaska (Kanevskiy et al., 2011). The late Pleistocene landscape has been extensively eroded by thermokarst in post-glacial time and is currently studded by thermokarst lakes and drained basins representing several generations of Holocene thermokarst formation (Charron, 1995; Jones et al., 2011). Hopkins and Kidd (1988) also describe the occurrence of thermokarst lake sediments from several lake generations in this region, the oldest of which potentially pre-date the Holocene and may be placed into the Last Interglacial or a late Pleistocene interstadial. Small streams such as the Kitluk River and a few remaining Yedoma remnants are other important relief features in the lowlands of the north-eastern Seward Peninsula, where our study site is located. Hydrostatic pingos rising more than $15 \mathrm{~m}$ above surrounding basin floors occur in numerous thermokarst basins in this region, indicating refreezing of the talik after lake drainage (Figs. 2 and 3).

Beside glaciations and permafrost dynamics, local lateQuaternary volcanism influenced past environmental dynamics with deposition of massive tephra layers and lava fields in some regions. According to Begét et al. (1996), the largest known maars on Earth, the Espenberg Maars, are located to the south of the study site (Fig. 1). The Devil Mountain Maar eruption was radiocarbondated to the LGM via the Kitluk palaeosol (see above), the South Killeak Maar is $>40$ ka old; the North Killeak Maar is somewhat older, and Whitefish Maar was probably formed 200-100 ka ago (Begét et al., 1996). Their tephra layers serve as stratigraphic markers for the late Pleistocene period (Höfle et al., 2000; Goetcheus and Birks, 2001) and are a locally important component of terrestrial and lacustrine sediment sequences.

The study area is covered with low tundra and shrub vegetation of the bioclimate subzone $\mathrm{D}$ (Raynolds et al., 2006). Wet sedge-moss communities with Carex aquatilis, Eriophorum angustifolium as well as Drepanocladus and Sphagnum dominate on wet-acidic sites. Tussock sedge (Eriophorum vaginatum) and dwarf shrub communities with Ledum palustre and Vaccinium vitis-idaea occupy higher and better drained sites. In drier habitats, such as pingos, there are 


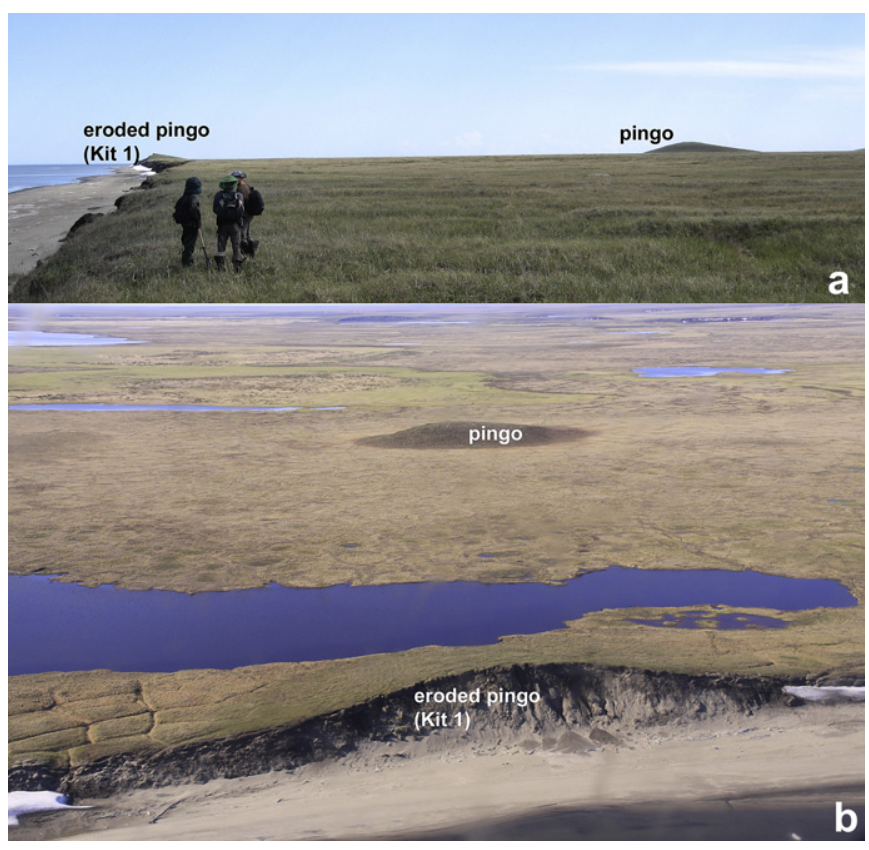

Fig. 3. Landscape overviews of the study site with an intact inland pingo and the sampled eroded pingo remnant (Kit 1 ) at the northern coast of Seward Peninsula (a) as seen from ground in June 2008, and (b) from an airplane in June 2010.

diverse dwarf and erect shrub communities with Andromeda polifolia, Betula nana, Spiraea beauverdiana, L. palustre and Dryas integrifolia. Here, and southward along the western Alaskan coast as far as $60^{\circ} \mathrm{N}$ latitude, the tree line retreats far inland (Fig. 1). This marked longitudinal biogeographic zonation illustrates the cooling effect of the adjacent Bering and Chukchi seas during the growing season. In contrast, under the more favourable continental climate farther inland, the tree line advances up to $68^{\circ} \mathrm{N}$ (Fig. 1 ).

\section{Material and methods}

The ca $16 \mathrm{~m}$ high coastal exposure was cleaned, then sediment and ground ice structures were described and sampled in frozen state in five sub-profiles (Fig. 4). The gravimetric ice content was determined as the ratio of the wet weight per sample to the dry sediment weight per sample expressed as weight percentage (wt\%) (van Everdingen, 1998).

In the laboratory, sediment samples were freeze-dried and split into sub-samples. For grain size analysis, sub-samples were first treated with hydrogen peroxide to remove organic matter and then measured in a laser particle analyser (Coulter LS 200). The massspecific mineral magnetic susceptibility (MS) was estimated with a Bartington MS2 and an MS2B-type sensor. The values of MS are expressed in SI units $\left(10^{-8} \mathrm{~m}^{3} \mathrm{~kg}^{-1}\right)$. The contents of total organic carbon (TOC), total carbon (TC), and total nitrogen (TN) were measured with a carbon-nitrogen-sulphur (CNS) analyser (Elementar Vario EL III), and expressed in weight percent (wt\%). The TOC/TN ratio was only calculated when the TN values were above the detection limit of $>0.05 \mathrm{wt} \%$. Stable carbon isotope composition $\left(\delta^{13} \mathrm{C}\right)$ of TOC (contents $>0.3 \mathrm{wt} \%$ ) was measured with a Finnigan DELTA S mass spectrometer. The values are expressed in delta per mil notation $(\delta, \%)$ relative to the Vienna Pee Dee Belemnite Standard (VPDB).

Fossil plant remains were radiocarbon-dated using the accelerator mass spectrometry (AMS) facilities at the Keck Carbon Cycle AMS Facility (University of California, Irvine, USA) and the Poznań Radiocarbon Laboratory (Adam Mickiewicz University, Poznań, Poland). Details on laboratory procedures are given by Santos et al.

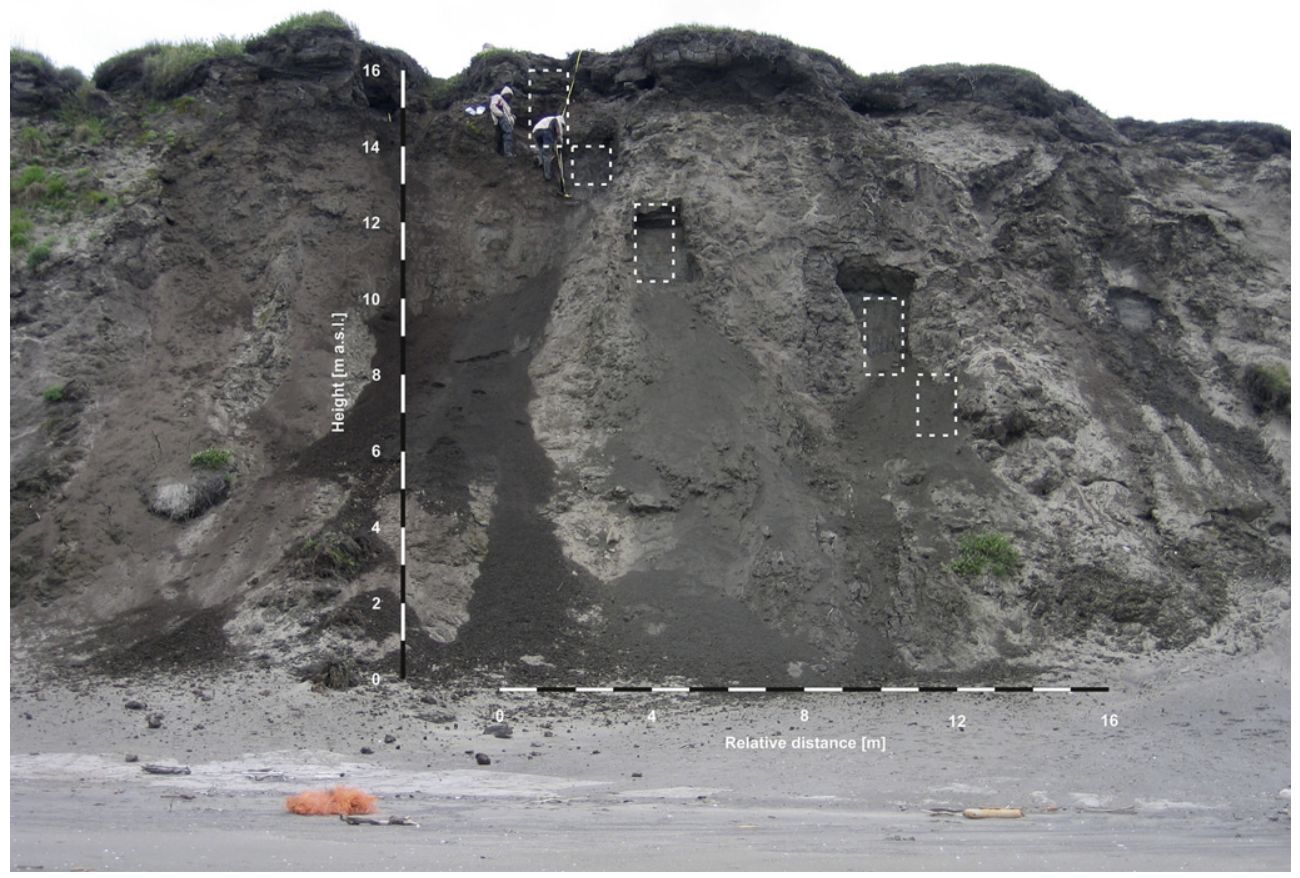

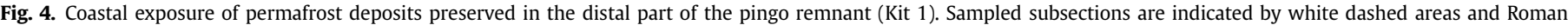

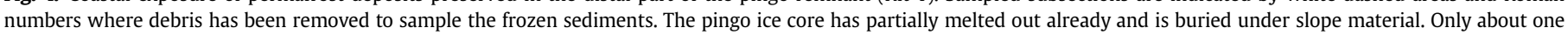
third of the pingo is remaining. 
(2007) and Goslar et al. (2004), respectively. Calibrated radiocarbon ages were calculated using the Calib Rev 6.0.0 program (Data set: IntCal09; Reimer et al., 2009).

For palaeontological analyses of vascular plant macrofossils, of gyrogonites, which are fossil calcareous remains of charophytes (algae of the family Characeae), and of ostracods, sediment subsamples were wet-sieved through 0.5 and $0.25 \mathrm{~mm}$ mesh screens, then air-dried and examined under stereo-microscopes (Zeiss Stemi SV 11, Olympus SZX 16). The identification was based on relevant species descriptions for plant macrofossils (Jessen, 1955; Berggren, 1969) and ostracods (Staplin, 1963a, 1963b; Swain, 1963; Delorme, 1968; Meisch, 2000; Smith and Delorme, 2010) and reference collections for plant remains at the Senckenberg Research Station for Quaternary Palaeontology (IQW) and for ostracods at the Alfred Wegener Institute. For scanning electron microscopy (SEM) images of gyrogonites, ostracod valves and ash particles we used a Zeiss Gemini Ultra+ device at the GeoForschungsZentrum Potsdam, Germany. For light microscope images, a Nikon D300 mounted on a Olympus SZX 16 stereo-microscope was used.

A standard technique was used for pollen preparation (Berglund and Ralska-Jasiewiczowa, 1986; Fægri and Iversen, 1989) by treating with $10 \% \mathrm{HCl}$ to remove carbonates, $10 \% \mathrm{KOH}$ to remove humic matter, $50 \% \mathrm{HF}$ ( $2 \mathrm{~h}$ boiling) to remove silicates, and acetolysis to remove cellulose from the samples. Finally, the samples were sieved $(7 \mu \mathrm{m})$ in an ultrasonic bath and mounted in water-free glycerol for storage and preparation of the microscopic slides. A tablet of Lycopodium marker spores was added to each sample for calculating total pollen and spore concentrations following Stockmarr (1971). Pollen and spores were identified at magnifications of $400 \times$ and $1000 \times$ (Zeiss Axioskop 2), with the aid of published pollen keys and atlases (Kupriyanova and Alyoshina, 1972, 1978; Bobrov et al., 1983; Reille, 1992, 1995, 1998; Beug, 2004). In addition to pollen and spores, a number of non-pollen palynomorphs such as fungi and algae remains were also identified (following van Geel, 2001 and references therein) when possible and counted. These non-pollen palynomorphs can also be used for interpretation of past environments. At least 250 pollen grains were counted in each sample. The relative frequencies were calculated from the sum of the pollen types. For other groups, percentages are based on the sum of pollen plus the sum of that group: spores, reworked types (mineralised pollen and spores of Tertiary and early Quaternary age), non-pollen palynomorphs, and algae. The Tilia/TiliaGraph/TGView software (Grimm, 1991, 2004) was used for the calculation of percentages and for drawing the diagrams. The diagrams were zoned by a qualitative inspection of significant changes in pollen associations, pollen concentration and the occurrence of particularly indicative types (e.g. tree pollen).

For testate amoebae (rhizopod) analysis sub-samples of about $3 \mathrm{~g}$ were first suspended in distilled water and passed through a 0.5$\mathrm{mm}$ meshed sieve to remove large masking organic and mineral particles. The next day a drop of suspension mixed with a drop of glycerine was added on a glass slide. The samples were counted under light microscope at 100-400× magnification (Zeiss Axioskop 2 ). On the average, five slides were examined for each sample.

\section{Results}

\subsection{Sedimentology and cryolithology}

Four sediment units were differentiated according to their sedimentological and cryolithological properties (Figs. 5 and 6).

The lowest exposed sediment, unit A (6.4-9.5 $\mathrm{m}$ a.s.l.), consists of grey-brown non-bedded silt (mean grain size $40-73 \mu \mathrm{m}$ ). The magnetic susceptibility shows little variation, lying between 43 and $48 \times 10^{-8} \mathrm{~m}^{3} \mathrm{~kg}^{-1}$ which are the highest values for the studied profile. The cryostructure is massive and the gravimetric ice content is low (18-26 wt\%), although individual vertical icefilled fissures and horizontal ice veins could be observed which likely represent secondary relaxation structures formed during erosion and exposure of the pingo. Organic matter is preserved as plant detritus, peat lenses, and twig fragments $(\varnothing 5-10 \mathrm{~mm})$. The TOC content is low reaching up to $1.6 \mathrm{wt} \%$ only in one sample. $\delta^{13} \mathrm{C}$ values vary little between -26.2 and $-25.7 \%$.

The next higher sediment, unit B (9.5-13.8 $\mathrm{m}$ a.s.l.), is composed of light grey-brown (reddish) silt and fine sand layers (mean grain size between 20 and $130 \mu \mathrm{m}$ ) that are weakly bedded in the lower part and ripple bedded in the upper part. Two layers with higher contents of fine volcanic ash particles (Fig. 5) were identified at heights of about 11.8 and $13.8 \mathrm{~m}$ a.s.l. Tephra particles of the lower layer are larger in size and have a less angular shape compared to particles from the upper ash-rich layer (SOM 1).

A sub-vertically oriented deformation of sedimentary structures was visible between about 11 and $12 \mathrm{~m}$ a.s.l. Magnetic susceptibility shows a general trend of decreasing values with increasing height from about 40 to $20 \times 10^{-8} \mathrm{~m}^{3} \mathrm{~kg}^{-1}$, with one exception at $11.75 \mathrm{~m}$ a.s.l. The cryostructure is mostly massive, but rare ice-filled vertical fissures, horizontal ice veins and irregular small ice lenses lead to gravimetric ice contents of up to $44 \mathrm{wt} \%$.

Bedded plant detritus and twig fragments (diameter ø 5-10 mm) are common in unit $\mathrm{B}$, where highest TOC contents reach up to $2.8 \mathrm{wt} \%$, while $\delta^{13} \mathrm{C}$ values vary between -28.3 and $-25.3 \%$ and decrease to more negative values in the upper part of unit B. Fossil freshwater mollusc remains (ø $2-5 \mathrm{~mm}$ ) are common in all of unit $\mathrm{B}$ pointing to a lacustrine origin for these sediments. Despite the common lacustrine character of unit B, its sedimentological properties reveal a division into two subunits at about $12 \mathrm{~m}$ a.s.l., with a coarser mean grain size, poorer sorting, some higher TOC values, decreasing $\delta^{13} \mathrm{C}$ and lower MS in the upper part of unit B compared to its lower part. These changes in sedimentology and biogeochemistry are likely linked to in the thermokarst lake formation that in its initial stage mainly reworked surrounding and underlying older material before the lake system became more stable, and the sedimentation changed from allochthonous to autochtonous sources.

The overlying sediment, unit C (13.8-14.7 $\mathrm{m}$ a.s.l.), is represented by light grey-brown layers of non-bedded silt and fine sand (mean grain size varying between 50 and $106 \mu \mathrm{m}$ ). The lower portion of unit $C$ contains tephra grains that likely are reworked material from the ash layer in the upper part of unit $B$. The magnetic susceptibility reaches values up to $25.5 \times 10^{-8} \mathrm{~m}^{3} \mathrm{~kg}^{-1}$. The cryostructure is net-like and features reticulated and partly icefilled vertical fissures; horizontal ice veins are also present (gravimetric ice content between 33 and $60 \mathrm{wt} \%$ ). The TOC content is very low, between about 0.5 and $0.8 \mathrm{wt} \%$, with $\delta^{13} \mathrm{C}$ on TOC values of about $-27.6 \%$. Occasional fossil mollusc remains occur in the lowermost part of unit C.

The uppermost sediment, unit D (14.7-16 $\mathrm{m}$ a.s.l.), is frozen in the lower part and reaches into the unfrozen active layer in its upper part. The profile contains layers of dark brown non-bedded silt and fine sand (mean grain size varying between 30 and $124 \mu \mathrm{m}$ ). The sediments are rich in organic matter, which is present as plant detritus, in-situ roots, twig fragments and platy peat lenses (20-40 mm long) leading to TOC values up to $7.5 \mathrm{wt} \%$ with $\delta^{13} \mathrm{C}$ values of about $-27.2 \%$.

\subsection{Geochronology}

The geochronology of the studied sequence is based on thirteen radiocarbon AMS ages from plant remains out of eleven sediment samples (Table 1). These dates indicate a mid-Wisconsin accumulation 


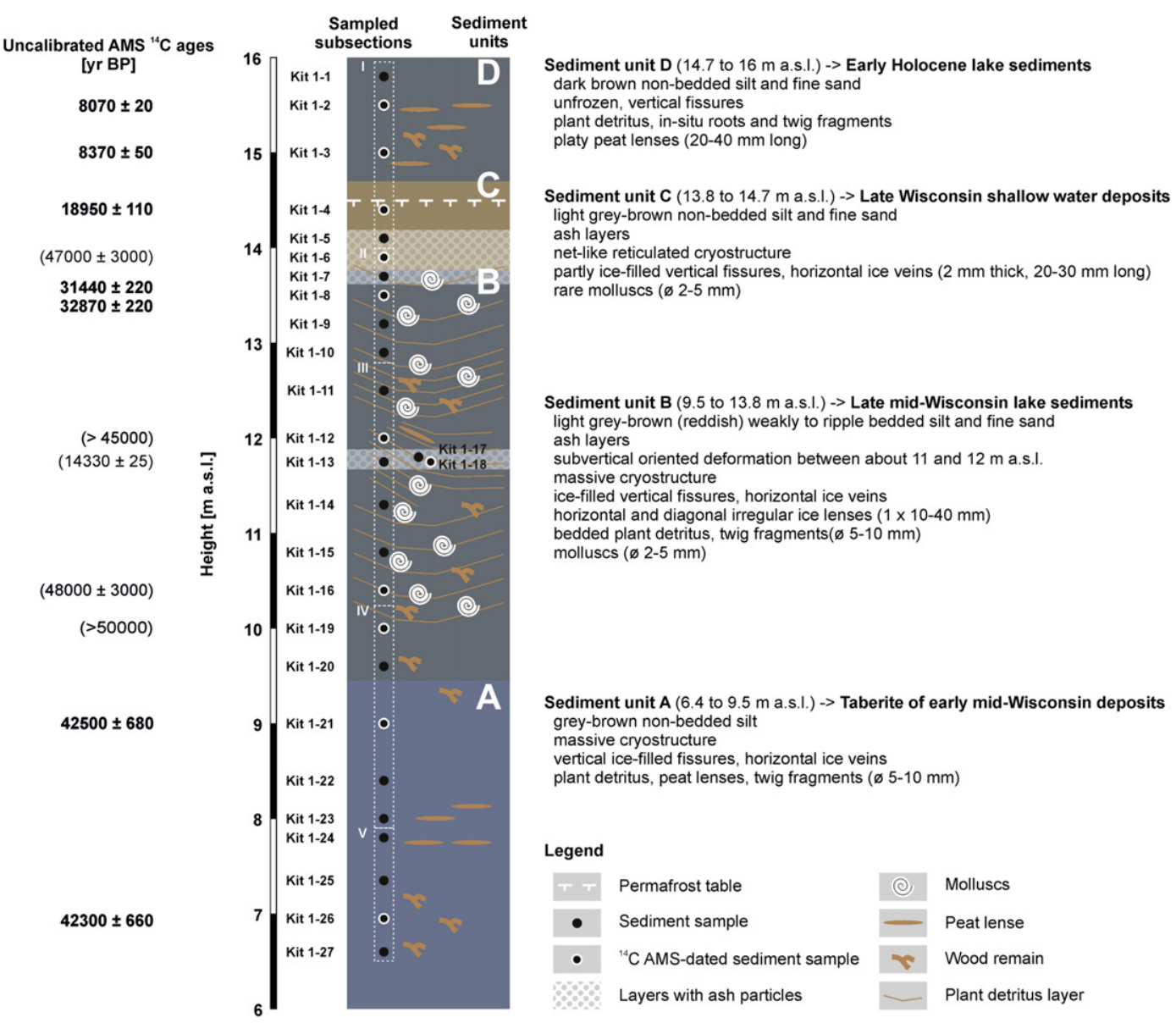

Fig. 5. Stratigraphic scheme of the studied pingo remnant exposure Kit 1 . Ages that were believed to be unreliable due to reworking and thus rejected for the age model are given in brackets.

between about 42-32 ka BP for the lowermost units A and B, including the presence of locally reworked material of Lateglacial origin (sample Kit 1-18, 14.3 ka BP) in a deformation structure, possibly an ice wedge cast penetrating into the mid-Wisconsin sediments. Age reversals in unit B, where some dates are older than those of the underlying sediments of unit A are likely caused by lacustrine reworking of older sediments in which the assumed thermokarst lake developed. In thermokarst lakes, thermal erosion and

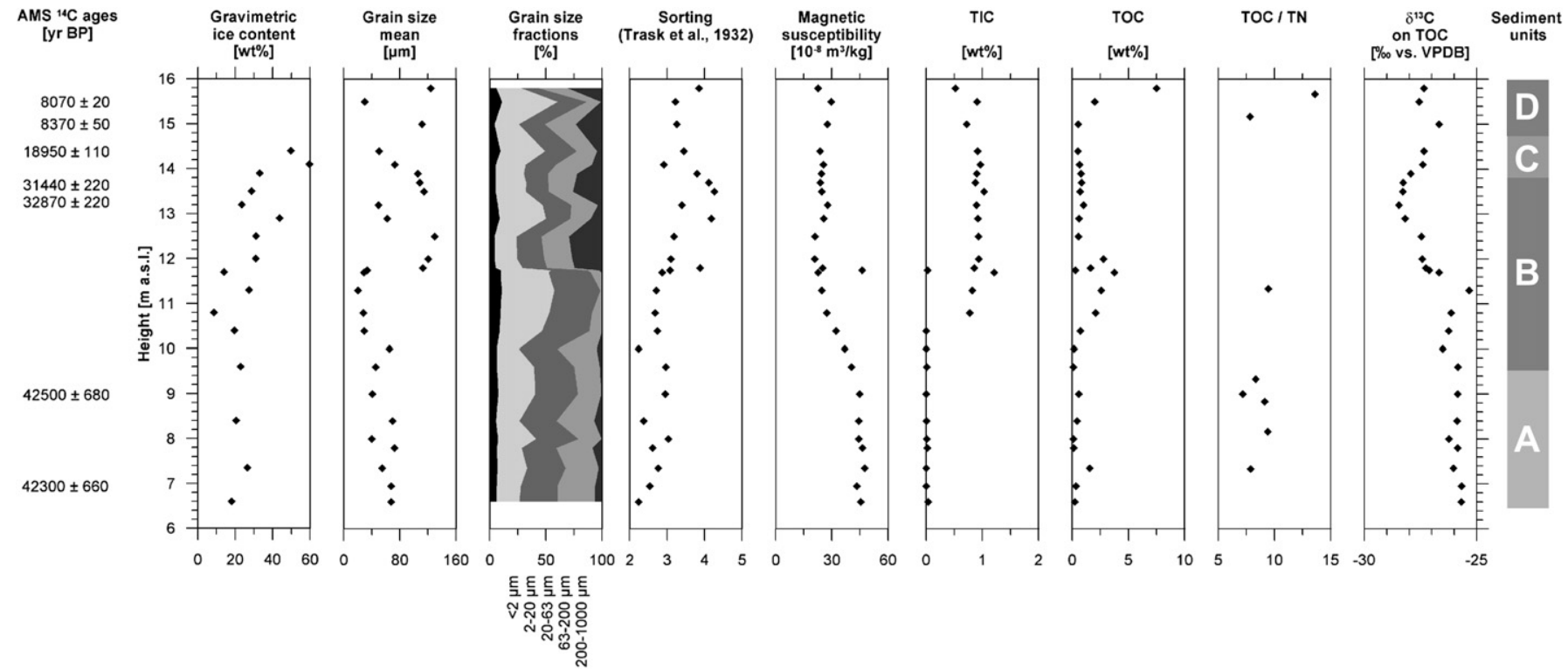

Fig. 6. Cryolithological data of the studied pingo remnant exposure Kit 1. 
Table 1

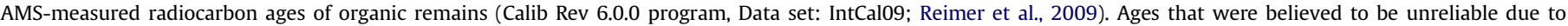
reworking and thus rejected for the age model are given in brackets.

\begin{tabular}{|c|c|c|c|c|c|}
\hline Sample No & Lab No & Material & Height [m a.s.l.] & ${ }^{14} \mathrm{C}$ ages [yr BP] & $\begin{array}{l}\text { Calibrated }{ }^{14} \mathrm{C} \text { ages } \\
(2 \sigma)[\mathrm{yr} \text { cal BP] }\end{array}$ \\
\hline Kit $1-2$ & UCIT18948 & peat & 15.5 & $8070 \pm 20$ & $8986-9027$ \\
\hline Kit $1-3$ & Poz-41901 & spruce twig & 15 & $8250 \pm 100$ & $9012-9462$ \\
\hline Kit $1-3$ & Poz-32501 & plant detritus & 15 & $8370 \pm 50$ & $9265-9495$ \\
\hline Kit $1-4$ & Poz-32502 & plant detritus & 14.4 & $18,950 \pm 110$ & $22,247-22,999$ \\
\hline Kit $1-6$ & Poz-32504 & wood fragments & 13.9 & $(47,000 \pm 3000)$ & \\
\hline Kit $1-8$ & UCIT18949R & plant detritus & 13.5 & $31,440 \pm 220$ & $35,216-36,509$ \\
\hline Kit $1-8$ & UCIT18949 & plant detritus & 13.5 & $32,870 \pm 220$ & $36,771-38,434$ \\
\hline Kit $1-12$ & Poz-32498 & wood fragments & 12 & $(>45,000)$ & \\
\hline Kit $1-18$ & UCIT18950 & plant detritus & 11.75 & $(14,330 \pm 25)$ & $17,118-17,745$ \\
\hline Kit $1-16$ & Poz-32499 & peat & 10.4 & $(48,000 \pm 3000)$ & \\
\hline Kit $1-19$ & Poz-32500 & wood fragments & 10 & $(>50,000)$ & \\
\hline Kit $1-21$ & UCIT18951 & plant detritus & 9 & $42,500 \pm 680$ & $44,625-46,893$ \\
\hline Kit $1-26$ & UCIT18952 & plant detritus & 6.95 & $42,300 \pm 660$ & $44,555-46,615$ \\
\hline
\end{tabular}

thaw slumping of shore banks delivers a large flux of sediments into the lake. In small young lakes, this results in significant input of older sediment and organic matter to the near-shore lake bottom. With increasing lake size, central lake portions become more distal from eroding shores, receive less input of old reworked sediment, and instead accumulate sediment from finer grain fractions that travel farther in suspension and from in-situ production of organic matter. Hence, with increasing lake size and possibly age, dates may provide a more correct accumulation age for the lacustrine sediments. Such problems in dating initiation of thermokarst lacustrine sediments and repeated age reversals due to reworked sediments are already known from a number of other studies (Hopkins and Kidd, 1988; Murton, 1996).

An age discordance was found between mid-Wisconsin unit $B$ (top ca $32 \mathrm{ka} \mathrm{BP}$ ) and late-Wisconsin unit C (ca $19 \mathrm{ka} \mathrm{BP}$ ). A second age discordance was found between unit $C$ and following Holocene unit D (bottom ca 8.4 ka BP).

As explained above, we took some ages to be unreliable due to reworking and thus rejected for the age model based on a combination of stratigraphical and palaeoecological context. Samples clearly reworked by periglacial processes (i.e. thermokarst) are given in Table 1 and in Fig. 5 in brackets. Two non-finite ages in unit $\mathrm{B}$ are related to material age above the dating limit of the radiocarbon method.

\subsection{Palaeoecological proxy data}

\subsubsection{Pollen}

The studied pollen spectra can be subdivided into four pollen zones (Fig. 7). The positions of the uppermost two pollen zones (III and IV) match the sediment units $C$ and $D$, respectively. However, the lower pollen zones I (a, b, c) and II span units A and B and do not coincide with observed stratigraphic boundaries.

The single sample representing pollen zone Ia (6.5-6.75 $\mathrm{m}$ a.s.l.) is characterised by high amounts of Betula and Salix pollen. Cyperaceae and Poaceae are also very common. The pollen concentration is rather high with 12,800 grains per gram $\left(\mathrm{gr} \mathrm{g}^{-1}\right)$. PZ-Ib and PZ-Ic (6.75-12.25 $\mathrm{m}$ a.s.l.) are notable for their high content of Picea pollen, while Betula values are lower in many samples in comparison with PZ-Ia. Pollen concentration varies greatly between 1330 and 66,000 $\mathrm{gr} \mathrm{g}^{-1}$ and reach the highest values in the PZ-Ic, which is also characterised by larger amounts of Betula pollen and a decrease in Picea pollen. Presence, in low amounts, of Larix and Ericales pollen grains and high amounts of Glomus spores are also characteristic for the zone. There are also numerous spores of coprophilous fungi (Sordaria, Podospora, Sporormiella) and the algae Botryococcus and Pediastrum. The overall character of PZ-I is unusual. The lower part of this zone is dominated by initially by Picea, which suggests tree cover at least to the degree of a woodland or parkland. Betula and Ericales values are low compared with Holocene samples from open forest or shrub tundra, while Poaceae and Cyperaceae values are high. The later part PZ-Ic is dominated by Betula, Poaceae and Cyperaceae. Pollen concentration is higher (up to $118,000 \mathrm{gr} \mathrm{g}^{-1}$ ) in PZ-II (12.25-13.75 $\mathrm{m}$ a.s.l.). This zone is characterised grass-sedge assemblages similar to those interpreted as a tundra-steppe community by many authors (for overview see Anderson et al., 2004), and by the disappearance of Ericales and only sporadic occurrences of pollen of Picea and Larix. The grass-sedge tundrasteppe of PZ-III (13.75-14.75 m a.s.l.) is notable for the further decrease in tree and shrub pollen and dramatic increase in Pediastrum remains pointing to shallow-water conditions (Anderson and Brubaker, 1986). Pollen concentration is the highest (up to 1,334,900 gr g $^{-1}$ ) in PZ-IV (14.75-15.75 m a.s.l.), which is dominated by pollen of Betula, Ericales, Cyperaceae, and Poaceae. Sphagnum spores are also very common in the zone. Pollen spectra resemble those of high-shrub tundra in PZ-IV.

\subsubsection{Plant and algae macrofossils}

Nineteen samples of the Kit 1 exposure were initially scanned for plant macrofossil content (SOM 2). Samples of unit A yielded no plant macrofossils. The lowest samples examined with plant macrofossils originate from unit B and contain numerous remains of aquatic plants including gyrogonites (remains of submersed Characeae algae) (Table 2, SOM 2, Fig. 8).

Only four samples (Kit $1-3$, Kit 1-6, Kit 1-11, Kit 1-17) exceeded the minimum amount of 50 individuals, which is required to avoid errors and biases in paleoecological interpretation (Forcino et al., 2012), and were selected for detailed analysis (Table 2). All four samples studied in detail as well as several others scanned initially contained remains of aquatic plants, supporting the interpretation that the sediments of units $B, C$ and $D$ are of lacustrine origin. At the top of the eroded pingo, the uppermost deposits of the sequence (lower part of unit D, Fig. 5) additionally contained fish vertebrae, statoblasts of the freshwater bryozoan Cristatella mucedo and numerous remains of warmth-demanding aquatic plants, indicating a significant increase in bioproductivity. The macrofossil-rich sample Kit 1-3 was AMS radiocarbon-dated to $8370 \pm 50 \mathrm{yr}$ BP; this sample was in the focus of a detailed analysis. The modern terrestrial plant cover is represented by A. polifolia, Empetrum nigrum, L. palustre, Betula nana/glandulosa, and Oxycoccus microcarpus. However, there are also fossils of numerous extralimital plant species. Examples are aquatic and marshland taxa such as Cicuta mackenzieana, Potamogeton alpinus ssp. tenuifolius, Potamogeton gramineus, Potamogeton praelongus, Callitriche 


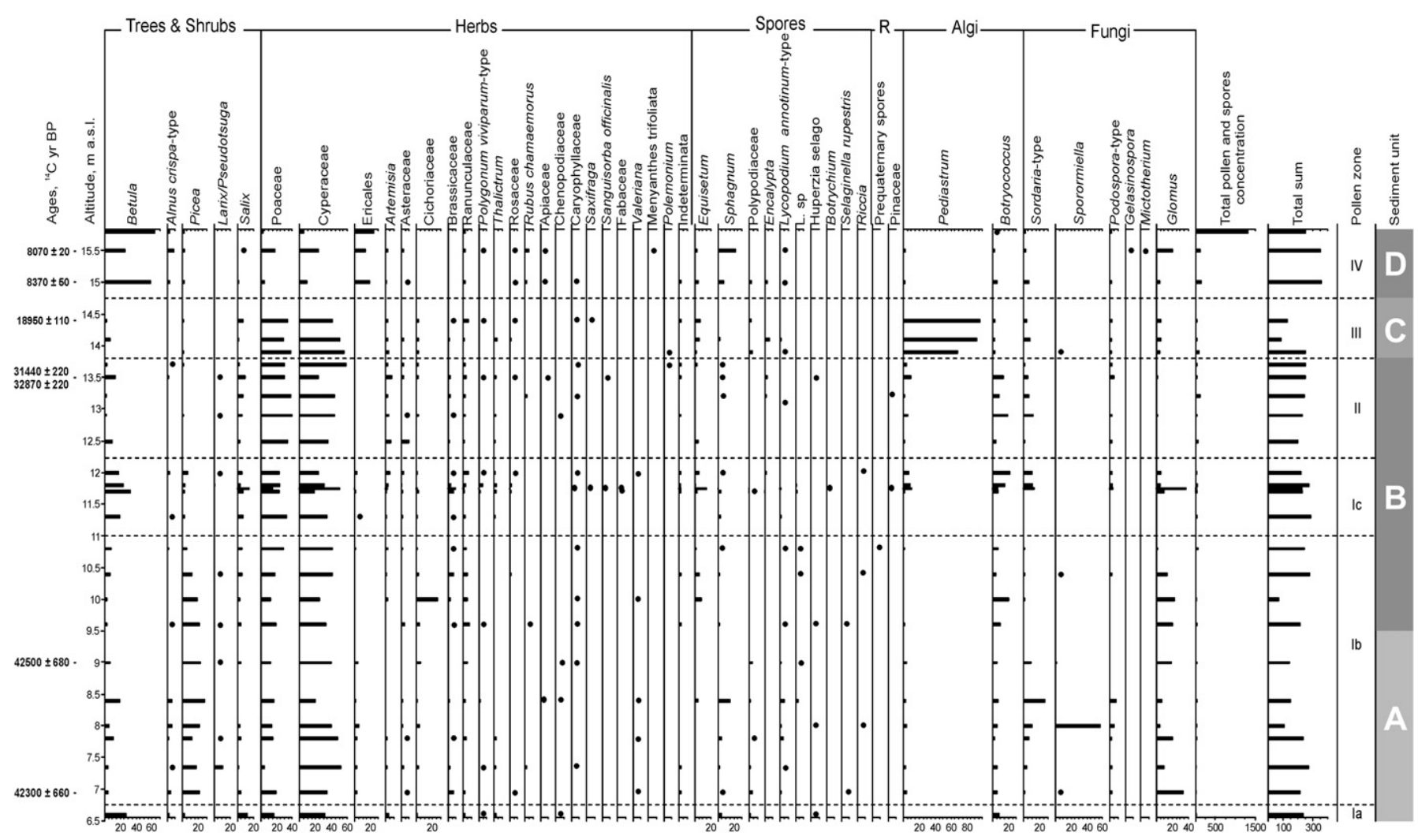

Fig. 7. Pollen counts in all samples of the studied pingo remnant exposure Kit 1. Note different scales for pollen type counts.

hermaphroditica and Ceratophyllum demersum as well as the woody taxa Chamaedaphne calyculata and Picea sp. The latter is assumed to belong to Picea glauca rather than to Picea mariana since P. glauca is today distributed further north and closer to the study site than $P$. mariana. Since young twigs of $P$. mariana are pubescent, the absence of hairs at the twig is an indication, even though not firm evidence, for $P$. glauca. Given the small size of the twig and the existing attachment scars at the very end of the twig, it is obvious that it originated from a young branchlet, which seems to have been glabrous as in P. glauca. The spruce macro-remain (Fig. 9) was dated individually to exclude redeposition from older (Last Interglacial) sediments. The obtained AMS date of $8250 \pm 100 \mathrm{yr}$ BP corresponds very well with the date of the source sample Kit 1-3 $(8370 \pm 50 \mathrm{yr}$ BP) (Table 1). Redeposition can thus be excluded.

\subsubsection{Ostracods and molluscs}

The lowermost unit A, attributed to the mid-Wisconsin, generally lacks any fossil remains of molluscs and ostracods, pointing to nonlacustrine origin of these deposits or conditions unfavourable for most aquatic organisms such as extended ice coverage. In contrast, the overlying mid-Wisconsin unit B contains remains of freshwater organisms, rich in individuals and species (Figs. 8 and 10). Mollusc remains, mostly as broken fragments, are found in most samples of unit B. The ostracod fauna of unit B consists of 16 species out of 8 genera (Fig. 8; SOM 3). The taxon Candoninae comprises ambiguous juvenile stages of the genera Candona and Fabaeformiscandona.

In the lower part of unit B (below $12.6 \mathrm{~m}$ a.s.l.), ostracod abundance and diversity are rather low; 11 species were identified. In the upper part (above $12.6 \mathrm{~m}$ a.s.l.) ostracod abundance and diversity are higher, and 14 species were identified, of which Cytherissa lacustris, Candona ikpukpuensis and Cypria ophtalmica are the most common. Unit C contains rare ostracods (seven species) and molluscs (Fig. 8). The uppermost unit D contains only one fossil of Cy. ophtalmica.

\subsubsection{Testate amoebae (rhizopods)}

All samples from profile Kit 1 were studied for shells of testate amoebae, of which six samples yielded remains (Fig. 11). The lowermost samples of unit A (Kit 1-27 and Kit 1-26) were barren, but samples Kit 1-25, Kit 1-24, and Kit 1-22 (unit A) contained taxa such as the eurybiotic Centropyxis sylvatica and Centropyxis sylvatica v. minor. The upper part of unit $A$ and all of units $B$ and $C$ were barren. Hygro- and hydrophilic rhizopod species of the genera Difflugia, Lagenodifflugia, and Centropyxis were found in the uppermost part of unit D; sphagnophilic Trigonopyxis arcula, Heleopera petricola, and Nebela tincta are present in sample Kit 1-2, and in Kit 1-1 the eurybiotic Cyclopyxis eurystoma v. parvula was found.

\section{Discussion}

\subsection{Local landscape dynamics}

The sequence of permafrost deposits preserved in the pingo represents an archive of palaeoenvironmental information reaching back to the mid-Wisconsin, and it provides insights into periglacial landscape development from the interstadial period through to the late Holocene. Thermokarst dominates as a process through much of the period, and the local landscape history terminates with pingo formation and subsequent coastal erosion in the late Holocene (Fig. 12). Thermokarst and pingo formation may influence the stratigraphic order of deposits and hence the geochronology due to disruption of accumulation or reworking of sediments. Both would be expressed as stratigraphic discordances in a cryostratigraphic sequence, and such discordance is observed 
Table 2

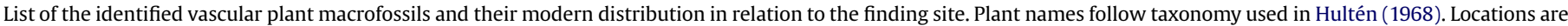

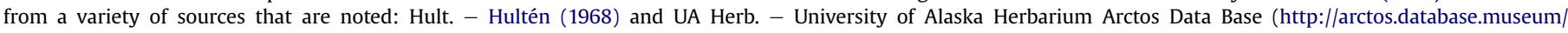
SpecimenSearch.cfm).

\begin{tabular}{|c|c|c|c|c|c|c|}
\hline \multirow[t]{2}{*}{ Family } & \multirow[t]{2}{*}{ Taxon } & \multicolumn{4}{|c|}{ Number and organ type of individuals } & \multirow[t]{2}{*}{ Modern distribution } \\
\hline & & $\begin{array}{l}\text { Kit } 1-03 \\
\text { Unit D }\end{array}$ & $\begin{array}{l}\text { Kit } 1-06 \\
\text { Unit } C\end{array}$ & $\begin{array}{l}\text { Kit } 1-11 \\
\text { Unit B }\end{array}$ & $\begin{array}{l}\text { Kit } 1-17 \\
\text { Unit B }\end{array}$ & \\
\hline Apiaceae & $\begin{array}{l}\text { Cicuta mackenzieana } \\
\text { Raup }\end{array}$ & 7 mericarps & & & & $\begin{array}{l}\text { not present at site or vicinity; but is } \\
\text { present in Escholtz Bay (Hult.) and } \\
\text { at Pilgrim Hot Springs (UA Herb.) }\end{array}$ \\
\hline Asteraceae & $\begin{array}{l}\text { Senecio congestus } \\
\text { (R. Br.) DC }\end{array}$ & & 29 achenes & $\begin{array}{l}2 \text { achene } \\
\text { fragm. }\end{array}$ & & present today in vicinity \\
\hline \multirow[t]{2}{*}{ Betulaceae } & $\begin{array}{l}\text { Betula nana } \mathrm{L} . \\
\text { Betula nana } \mathrm{L} .\end{array}$ & $\begin{array}{l}8 \text { leaf fragm. } \\
57 \text { nutlets }\end{array}$ & & & $\begin{array}{l}1 \text { nutlet } \\
\text { fragm. }\end{array}$ & $\begin{array}{l}\text { present today in vicinity } \\
\text { present today in vicinity }\end{array}$ \\
\hline & Betula nana $\mathrm{L}$. & 8 scales & & & & present today in vicinity \\
\hline Brassicaceae & $\begin{array}{l}\text { Brassicaceae indet. } \\
\text { Draba sp. }\end{array}$ & 1 seed & 2 seeds & & & $\begin{array}{l}\text { present today in vicinity } \\
\text { present today in vicinity }\end{array}$ \\
\hline Bryozoa & Cristatella mucedo Curvier & statoblasts & & & & \\
\hline Callitrichaceae & Callitriche hermaphroditica L. & 2 mericarps & 14 mericarps & & & $\begin{array}{l}\text { not present at site; but is present } \\
\text { in Escholtz Bay (Hult.) and southern } \\
\text { interior Seward Peninsula (UA Herb.). } \\
\text { present today in vicinity }\end{array}$ \\
\hline \multirow[t]{2}{*}{ Caryophyllaceae } & $\begin{array}{l}\text { Minuartia cf. Stricta } \\
\text { (Sw.) Hiern }\end{array}$ & & 1 seed & & & $\begin{array}{l}\text { not present at the site; nearest } \\
\text { occurrence southern Seward } \\
\text { Peninsula (UA Herb.); also present } \\
\text { eastern Chukotka (Hult.), southern } \\
\text { Brooks Range, and interior Alaska } \\
\text { (UA Herb. and Hult.) }\end{array}$ \\
\hline & $\begin{array}{l}\text { Moehringia laterifolia } \\
\text { (L.) Fenzl }\end{array}$ & 1 seed & & & & $\begin{array}{l}\text { not present at the site; closest } \\
\text { occurrence on dry localities at Cape } \\
\text { Espenberg and Serpentine Hot } \\
\text { Springs (UA Herb.) }\end{array}$ \\
\hline Ceratophyllaceae & Ceratophyllum demersum $\mathrm{L}$. & 18 fruits & & & & $\begin{array}{l}\text { extralimital, nearest occurrence } \\
\text { Yukon River, Central Alaska (Polar } \\
\text { Circle, } 146^{\circ} \text { W; Hulten, 1968), } \\
\text { Denali National, coast of } \\
\text { Kotzebue Sound }\end{array}$ \\
\hline \multirow[t]{2}{*}{ Characeae } & $\begin{array}{l}\text { Chara aspera/canescens } \\
\text { Chara cf. hispida L. }\end{array}$ & ca 100 oocytes & 1 oospore & 24 oospores & 28 oospores & \\
\hline & Nitella sp. & ca 100 oocytes & $\begin{array}{l}\text { ca } 150 \\
\text { oospores }\end{array}$ & $\begin{array}{l}\times 100 \\
\text { oocytes }\end{array}$ & $\begin{array}{l}\times 100 \\
\text { oospores }\end{array}$ & \\
\hline Chenopodiaceae & Chenopodiaceae sp. & & 2 seeds & & & $\begin{array}{l}\text { not present at the site; nearest } \\
\text { occurrence in Interior Alaska, } \\
\text { southern Yukon Territory, and } \\
\text { a single specimen in the eastern } \\
\text { Brooks Range (Hult.; UA Herb.) }\end{array}$ \\
\hline \multirow[t]{6}{*}{ Cyperaceae } & $\begin{array}{l}\text { Carex cf. capillaris L. } \\
\text { Carex rostrata Stokes }\end{array}$ & $\times 100$ fruits & & 1 nutlet & 23 nutlets & $\begin{array}{l}\text { present today in vicinity } \\
\text { not present at site; but is present in } \\
\text { Escholtz Bay and Kotzebue (Hult.) }\end{array}$ \\
\hline & Carex sect. phacocystis & 76 nutlets & 2 nutlets & 29 nutlets & ca 80 nutlets & present today in vicinity \\
\hline & Carex cf. saxatilis L. & & 2 nutlets & 2 nutlets & 21 nutlets & present today in vicinity \\
\hline & $\begin{array}{l}\text { Carex sp. } \\
\text { Eleocharis palustris (L.) } \\
\text { Roem. \& Schult. }\end{array}$ & $\begin{array}{l}135 \text { nutlets } \\
3 \text { fruits }\end{array}$ & 6 nutlets & 2 nutlets & & $\begin{array}{l}\text { present today in vicinity } \\
\text { not present in site vicinity; nearest } \\
\text { occurrence at Serpentine Hot Springs } \\
\text { and Kotzebue (UA Herb.) }\end{array}$ \\
\hline & $\begin{array}{l}\text { Eriophorum brachyantherum } \\
\text { Trautv. \& Mey. }\end{array}$ & 3 fruits & & & & present today in vicinity \\
\hline & $\begin{array}{l}\text { Trichophorum cespitosum } \\
\text { (L.) Hartm. }\end{array}$ & 1 fruit & 1 fruit & & & present today in vicinity \\
\hline \multirow[t]{2}{*}{ Empetraceae } & Empetrum nigrum s.l. L. & 27 seeds & & & & present today in vicinity \\
\hline & Empetrum nigrum s.l. L. & 29 leaves & & & & present today in vicinity \\
\hline \multirow[t]{8}{*}{ Ericaceae } & $\begin{array}{l}\text { Andromeda polifolia } \mathrm{L} . \\
\text { Andromeda polifolia } \mathrm{L} . \\
\text { Chamaedaphne calyculata } \\
\text { (L.) Moench }\end{array}$ & $\begin{array}{l}18 \text { leaves } \\
43 \text { seeds } \\
15 \text { seeds }\end{array}$ & & & & $\begin{array}{l}\text { present today in vicinity } \\
\text { present today in vicinity } \\
\text { not present at the site vicinity (?); } \\
\text { nearest occurrence interior Seward } \\
\text { Peninsula (UA Herb.) }\end{array}$ \\
\hline & $\begin{array}{l}\text { Chamaedaphne calyculata } \\
\text { (L.) Moench }\end{array}$ & 6 leaves & & & & $\begin{array}{l}\text { not present at the site vicinity (?); } \\
\text { nearest occurrence interior Seward } \\
\text { Peninsula (UA Herb.) }\end{array}$ \\
\hline & Ledum palustre $\mathrm{L}$. & 165 leaf fragm. & & & & present today in vicinity \\
\hline & Ledum palustre $\mathrm{L}$. & 6 capsule fragm. & & & & present today in vicinity \\
\hline & Oxycoccus microcarpus Turcz. & 1 seed & & & & present today in vicinity \\
\hline & Oxycoccus microcarpus Turcz. & 20 leaves & & & & present today in vicinity \\
\hline & Vaccinium vitis-idaea $\mathrm{L}$. & 3 seeds & & & & present today in vicinity \\
\hline & Vaccinium vitis-idaea $\mathrm{L}$. & 44 leaf fragm & & & & present today in vicinity \\
\hline
\end{tabular}


Table 2 (continued)

\begin{tabular}{|c|c|c|c|c|c|c|}
\hline \multirow[t]{2}{*}{ Family } & \multirow[t]{2}{*}{ Taxon } & \multicolumn{4}{|c|}{ Number and organ type of individuals } & \multirow[t]{2}{*}{ Modern distribution } \\
\hline & & $\begin{array}{l}\text { Kit } 1-03 \\
\text { Unit D }\end{array}$ & $\begin{array}{l}\text { Kit } 1-06 \\
\text { Unit C }\end{array}$ & $\begin{array}{l}\text { Kit } 1-11 \\
\text { Unit B }\end{array}$ & $\begin{array}{l}\text { Kit } 1-17 \\
\text { Unit B }\end{array}$ & \\
\hline \multirow[t]{2}{*}{ Haloragaceae } & $\begin{array}{l}\text { Myriophyllum } \\
\text { spicatum } \mathrm{L} .\end{array}$ & & & 2 mericarps & 1 mericarp & $\begin{array}{l}\text { not present at site vicinity; nearest } \\
\text { occurrence interior and southern } \\
\text { Seward Peninsula. Also present on } \\
\text { northern shore of Kotzebue Sound } \\
\text { (Hult., UA Herb.) }\end{array}$ \\
\hline & $\begin{array}{l}\text { Myriophyllum } \\
\text { verticillatum } \mathrm{L} .\end{array}$ & & & 1 mericarp & & $\begin{array}{l}\text { not at site vicinity; nearest occurrence } \\
\text { at Nome and on the coast just north of } \\
\text { Kotzebue Sound (UA Herb.); otherwise } \\
\text { it is typically found in the eastern } \\
\text { Alaska. }\end{array}$ \\
\hline Hippuridaceae & Hippuris vulgaris $\mathrm{L}$. & 48 fruits & & 4 fruits & 3 fruits & present today in vicinity \\
\hline Juncaceae & Luzula cf. Confusa Lindeb. & 1 seed & & 1 seed & & present today in vicinity \\
\hline Lentibulariaceae & Utricularia intermedia Hayne & 4 seeds & & & & present today in vicinity \\
\hline Menyanthaceae & Menyanthes trifoliata $\mathrm{L}$. & 125 seeds & & & & $\begin{array}{l}\text { not on Seward Peninsula, Alaska, south } \\
\text { of Brooks Range, closest occurrence } \\
\text { Escholtz Bay (Kotzebue Sound) }\end{array}$ \\
\hline Pinaceae & $\begin{array}{l}\text { Picea sp. (most likely } \\
\text { P. glauca) }\end{array}$ & $\begin{array}{l}1 \text { twig } \\
\text { fragment }\end{array}$ & & & & $\begin{array}{l}\text { extralimital, closest occurrence river } \\
\text { valleys in the southern part of Seward } \\
\text { Peninsula }\end{array}$ \\
\hline \multirow{3}{*}{ Poaceae } & Deschampsia sp. & 2 caryopsis & & & & present today in vicinity \\
\hline & Poa sp. & & 1 caryopsis & & & present today in vicinity \\
\hline & Puccinellia sp. & & 22 caryopses & & & present today in vicinity \\
\hline Portulacaceae & Montia fontana $\mathrm{L}$. & 1 seed & & & & present today in vicinity \\
\hline \multirow[t]{7}{*}{ Potamogetonaceae } & $\begin{array}{l}\text { Potamogeton alpinus } \\
\text { ssp. tenuifolius (Raf.) Hult. }\end{array}$ & 3 fruits & & & & $\begin{array}{l}\text { not present at site vicinity; nearest } \\
\text { occurrence at Escholtz Bay (Hult.) and } \\
\text { the southern Seward Peninsula near } \\
\text { Nome (UA Herb.) }\end{array}$ \\
\hline & Potamogeton filiformis Pers. & 4 fruits & 14 fruits & & & present today in vicinity \\
\hline & Potamogeton graminaeus L. & 6 fruits & & & & $\begin{array}{l}\text { not present at site vicinity; nearest } \\
\text { occurrence in the Escholtz Bay and } \\
\text { eastern Kotzebue Sound (Hult.; UA } \\
\text { Herb.) }\end{array}$ \\
\hline & Potamogeton perfoliatus L. & 4 fruits & & & & $\begin{array}{l}\text { not present at site vicinity; nearest } \\
\text { occurrence in the Escholtz Bay and } \\
\text { eastern Kotzebue Sound (Hult.; UA } \\
\text { Herb.) }\end{array}$ \\
\hline & Potamogeton praelongus Wulf. & 3 fruits & & & & $\begin{array}{l}\text { not present at site vicinity; closest } \\
\text { occurrence on southern Seward } \\
\text { Peninsula (near Nome; Hult.). Although } \\
\text { most specimens are from central and } \\
\text { eastern Alaska, south of the Brooks } \\
\text { Range (Hult.; UA Herb.) }\end{array}$ \\
\hline & Potamogeton vaginatus Turcz. & & & 17 fruits, 9 lids & 1 fruit & present today in vicinity \\
\hline & Potamogeton sp. & 4 fruits, 13 lids & & & & present today in vicinity \\
\hline \multirow[t]{9}{*}{ Ranunculaceae } & cf. Anemone sp. & & & & 1 fruit fragm. & present today in vicinity \\
\hline & $\begin{array}{l}\text { Ranunculus subgen. } \\
\text { Batrachium }\end{array}$ & 7 fruits & 3 fruits & & 1 fruit & $\begin{array}{l}\text { not present at site vicinity; closest } \\
\text { occurrence of Ranunculus trychophyllus } \\
\text { var. trychopyllus on southern Seward } \\
\text { Peninsula and at Point Hope (UA Herb.) }\end{array}$ \\
\hline & Caltha palustris s.l. L. & 5 seeds & & & & present today in vicinity \\
\hline & $\begin{array}{l}\text { Ranunculus pedatifidus subsp. } \\
\text { affinis (R. Br.) Hult. }\end{array}$ & 1 fruit & & & & present today in vicinity \\
\hline & Ranunculus cf. pallasii Schlecht. & 1 seed fragm. & & & & present today in vicinity \\
\hline & Ranunculus hyperboreus Rottb. & 4 fruits & 1 fruit & 5 fruits & 1 fruit & present today in vicinity \\
\hline & Ranunculus lapponicus L. & 9 fruits & & & & present today in vicinity \\
\hline & Ranunculus pygmaeus Wahlenb. & 3 fruits & 3 fruits & & 1 fruit & present today in vicinity \\
\hline & Ranunculus cf. turneri Greene & & & & 1 fruit & $\begin{array}{l}\text { not present at site vicinity; closest } \\
\text { occurrence at Point Hope (UA Herb.) } \\
\text { and St. Lawrence Island (Hult.); also } \\
\text { present in southern Chukotka } \\
\text { (Providenya; UA, Herb.) and the } \\
\text { northern Yukon Territory and } \\
\text { Mackenzie river delta (Hult.). }\end{array}$ \\
\hline \multirow[t]{3}{*}{ Rosaceae } & Potentilla palustris (L.) Scop. & 54 seeds & & & 4 fruits & present today in vicinity \\
\hline & Dryas integrifolia M. Vahl & 18 leaves & & & & present today in vicinity \\
\hline & $\begin{array}{l}\text { Potentilla sp. } \\
\text { cf. Spiraea sp. }\end{array}$ & 4 fruits & $\begin{array}{l}5 \text { fruits } \\
1 \text { seed }\end{array}$ & 1 fruit & & $\begin{array}{l}\text { present today in vicinity } \\
\text { present today in vicinity }\end{array}$ \\
\hline \multirow[t]{2}{*}{ Salicaceae } & Salix sp. & 1 capsule & & & & present today in vicinity \\
\hline & Salix sp. & 7 buds & & & 9 buds & present today in vicinity \\
\hline Scrophulariaceae & cf. Limosella aquatica $\mathrm{L}$. & 1 seed & & & & \\
\hline \multirow[t]{2}{*}{ Sparganiaceae } & $\begin{array}{l}\text { Sparganium cf. minimum } \\
\text { (Hartm.) E. Fries }\end{array}$ & 1 fruit & & & & $\begin{array}{l}\text { not present at site vicinity; nearest } \\
\text { occurrences well east and south of the }\end{array}$ \\
\hline & Sparganium hyperboreum Laest. & 3 fruits & & & & $\begin{array}{l}\text { Seward Peninsula (UA Herb., Hult.) } \\
\text { present today in vicinity }\end{array}$ \\
\hline
\end{tabular}




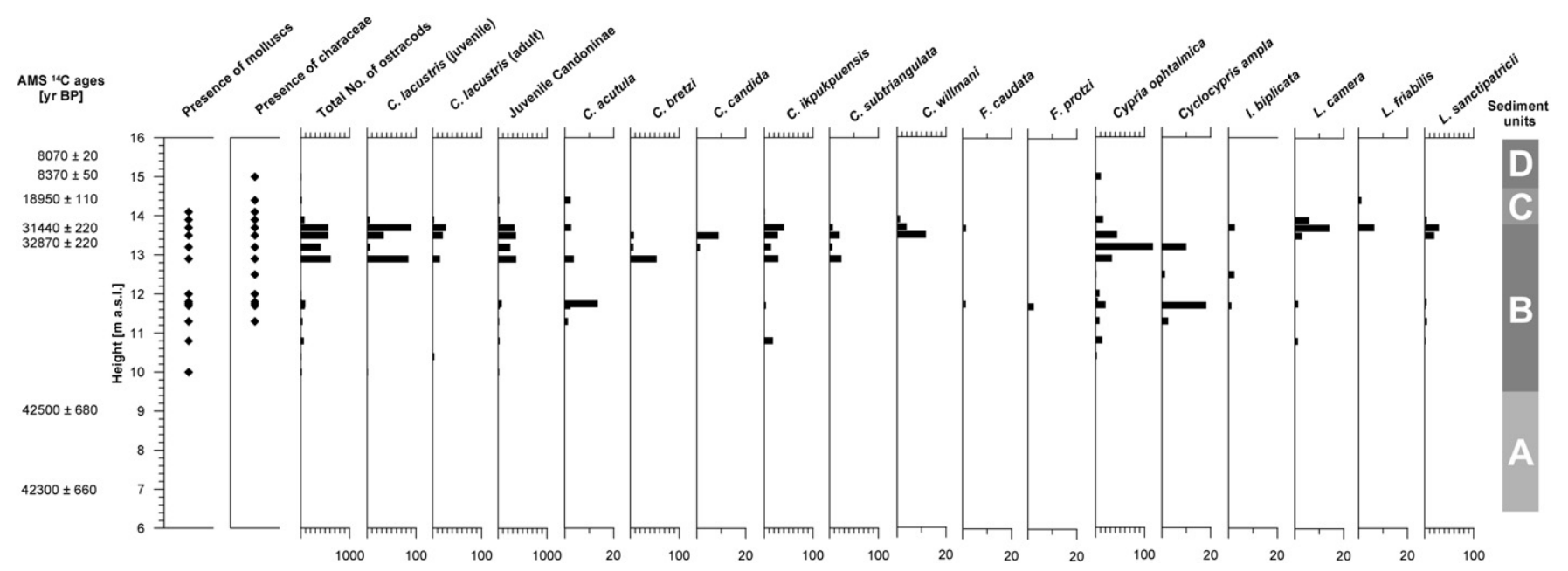

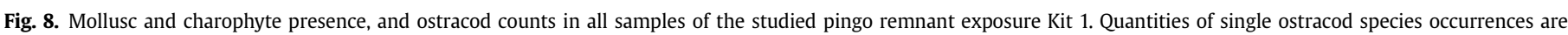
normalised to $25 \mathrm{~g}$ of dry sediment. Note different scales for taxa counts.

in this exposure. However, if the processes particular to this landscape and the related interruptions in sediment deposition are taken into account, valuable palaeoenvironmental information can be derived from such sequences.

The mid-Wisconsin interstadial period in our exposure is represented by thermokarst-related sediments commonly referred to taberal deposits (sediment unit A, 6.4-9.5 m a.s.l.). During warm stages or phases, surface subsidence due to the volume loss from melting, ground ice leads to the formation of (thermokarst) basins. In these basins meltwater and precipitation start pooling to form an initial thermokarst lake. Taberal deposits (taberites; e.g. Romanovskii, 1993; Romanovskii et al., 2004) originate when frozen sediments thaw below such inland waters, which induce thermal disturbance of the underlying permafrost. Unfrozen horizons below lakes within permafrost are called taliks (thaw bulbs; van Everdingen, 1998), and may refreeze after lake drainage or desiccation. Taberites as thawed and refrozen deposits are characterised by their stratigraphic position below lacustrine deposits, by very low ice contents, and almost no detectable ice and sediment structures. Formerly ice-rich permafrost dated to about $42.5 \mathrm{ka}$ BP and older (Fig. 12a) thawed during the formation of
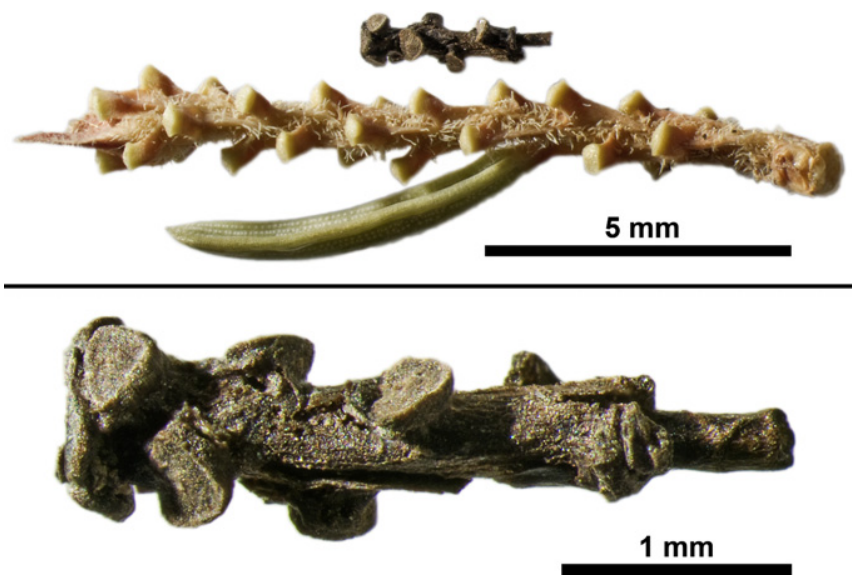

Fig. 9. Fossil spruce twig (Picea sp.) found in the early Holocene sample Kit 1-3 and dated separately to $8250 \pm 100 \mathrm{yr}$ BP (9012-9462 yr cal BP). The needle attachment scars as diagnostic feature are very distinct (compare modern twig of Picea mariana in the upper half of the figure with one attached needle). a mid-Wisconsin thermokarst lake (lacustrine deposits of sediment unit B, 9.5-13.8 $\mathrm{m}$ a.s.l.) (Fig. 12b). The lake persisted until about 32 ka BP. Its presence is indicated by lacustrine sediments containing fossil freshwater molluscs, ostracods, aquatic plant macroremains and aquatic algae. Radiocarbon dates of unit B reflect reworking of older material from unit A due to thawing and lake shore erosion at the margins of the thermokarst lake.

Hopkins and Kidd (1988) and Charron (1995) describe exposures on the northern Seward Peninsula that contain lacustrine sediments of Holocene thermokarst lakes as well as separate older lacustrine sequences. Though not absolutely dated, their older lacustrine sequences are interpreted as Wisconsin-age thermokarst lakes. Our radiocarbon-dated lacustrine sequences confirm the occurrence of lakes that formed as result of thermokarst processes during the mid-Wisconsin interstadial. The rhizopod remains found in unit A (Cen. sylvatica and Cen. sylvatica v. minor) indicate that soil formation took place under dry climate. These findings indicate that sufficient ice-rich permafrost sediments had accumulated prior to the interstadial, probably via deposition of loesslike material, so that thermokarst lake development involving permafrost thawing, surface subsidence, and water pooling could then take place during the warmer interstadial period.

The discordantly overlying late-Wisconsin sediment unit $\mathrm{C}$ (13.8-14.7 m a.s.l.) dated to about 19 ka BP likely represents a shallow-water environment as reflected by high green algae (Pediastrum) concentrations and rather sparse ostracod and mollusc findings. These indications point to less favourable lacustrine conditions, which can be explained with dryer and colder climate conditions during the LGM. Drainage or desiccation of the interstadial lake during that period was quite possibly accompanied by increased deposition of eolian silt, ice wedge growth, accumulation of segregated ground ice, and formation of polygon ponds (Fig. 12c). Continuous Yedoma accumulation has been demonstrated in the study area for the LGM period by numerous studies focusing on the LGM Kitluk palaeosol (Höfle and Ping, 1996; Höfle et al., 2000). Virtual disappearance of tree and shrub pollen suggests colder climate conditions than before, and this is in agreement with palaeobotanical data indicating dry tundra condition from the LGM Kitluk palaeosol (Goetcheus and Birks, 2001).

A deformation structure originating from unit $C$ and penetrating into underlying unit B with a young radiocarbon age of ca $14.4 \mathrm{ka} B P$ may indicate an ice wedge cast, and thus former presence of ice wedges that likely formed during accumulation of unit $\mathrm{C}$. 


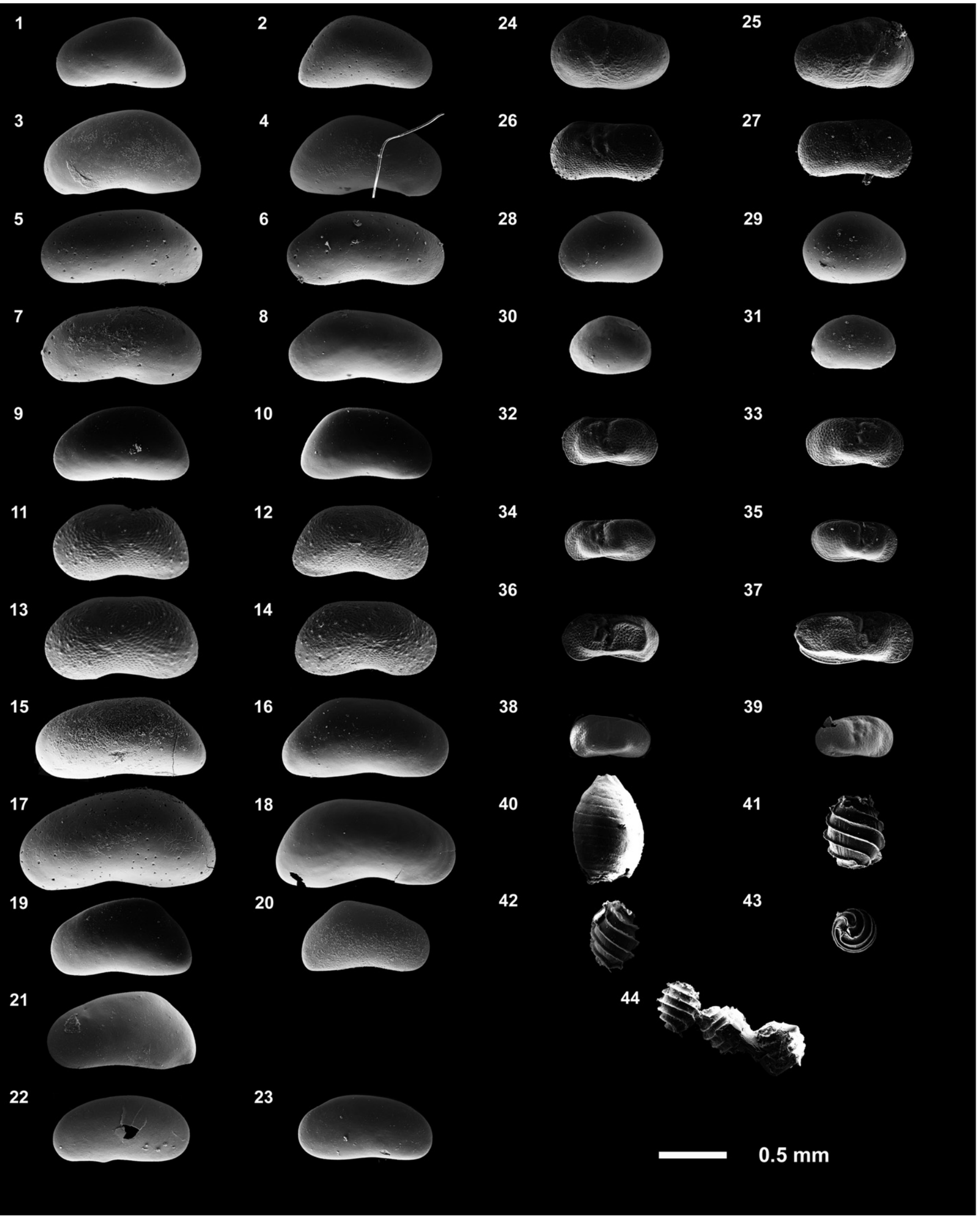

Fig. 10. SEM images of fossil ostracod valves (LV - left valve, RV - right valve) and diverse charophyte nucules (gyrogonites). Candona acutula: (1) female LV, (2) female RV, (3) male LV, (4) male RV; Candona bretzi: (5) female LV, (6) female RV, (7) male LV, (8) male RV; Candona candida: (9) female LV, (10) female RV; Candona ikpukpuensis: (11) female LV, (12) female RV, (13) male LV, (14) male RV; Candona subtriangulata: (15) female LV, (16) female RV, (17) male LV, (18) male RV; Candona willmani: (19) female LV, (20) female RV; Fabaeformiscandona caudata: (21) female LV; Fabaeformiscandona protzi: (22) female LV, (23) female RV; Cytherissa lacustris: (24) female LV, (25) female RV; Ilyocypris biplicata: (26) female LV, (27) female RV; Cypria ophtalmica: (28) female LV, (29) female RV; Cyclocypris ampla: (30) female LV, (31) female RV; Limnocytherina sanctipatricii: (32) female LV, (33) female RV, (34) male LV, (35) male RV; Limnocythere camera: (36) female LV, (37) male RV; Limnocytherina friabilis: (38) female LV, (39) female RV; diverse gyrogonites: (40-44). 


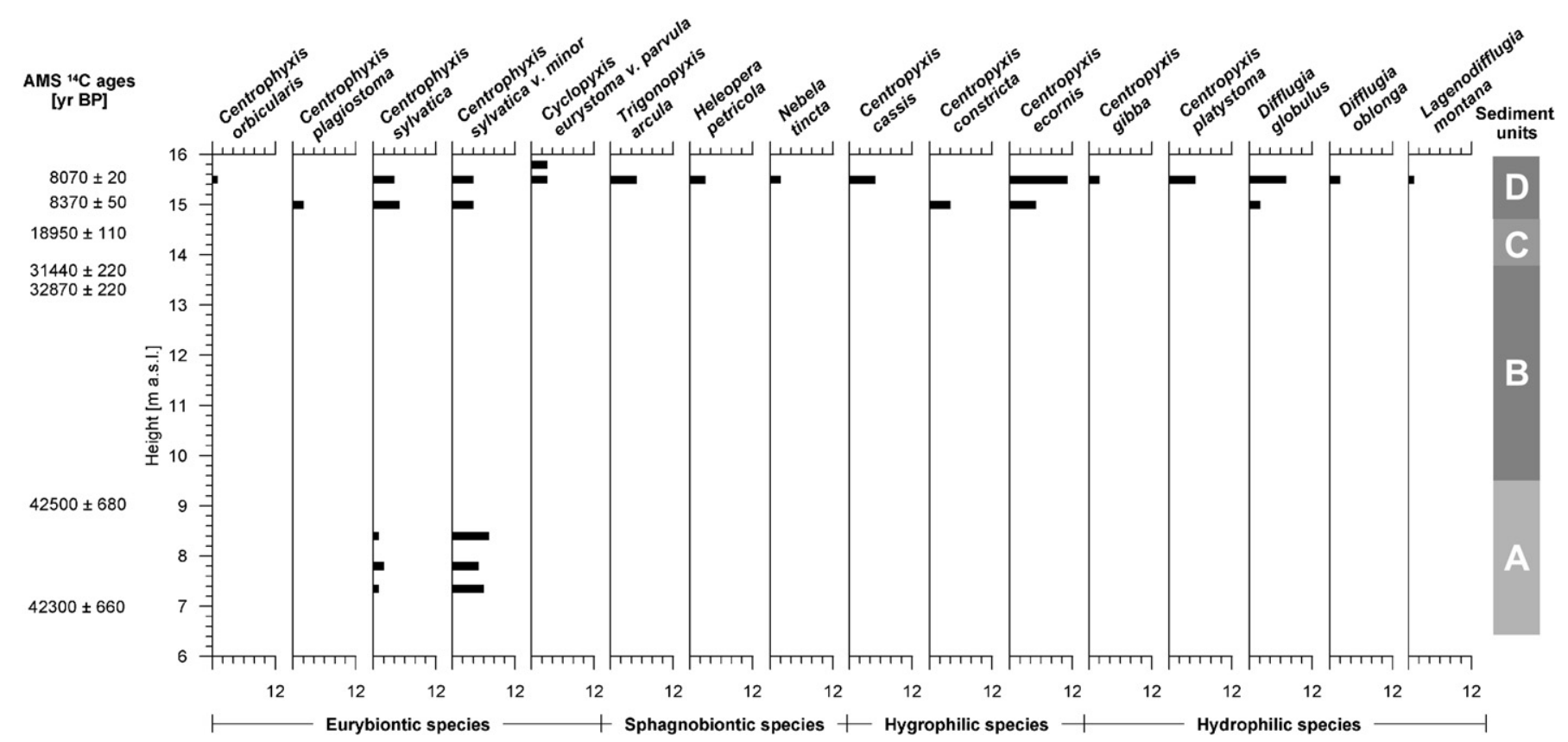

Fig. 11. Rhizopod counts in all samples of the studied pingo remnant exposure Kit 1.

The early Holocene unit D (14.7-16 m a.s.l.), dated to about 9 ka BP, accumulated under moister and warmer conditions that led to renewed thermokarst lake development in the basin that had existed at least since the mid-Wisconsin thermokarst event (Fig. 12d). Permafrost degradation during this warm period was expressed by formation of ice-wedge casts (McCulloch and Hopkins, 1966) and thermokarst lakes (Hopkins and Kidd, 1988). Throughout the Holocene, thermokarst processes have continued to operate, gradually lowering the original land surface. Thermokarst lake formation during that time falls within the range of other published thermokarst lake basal dates for the Seward Peninsula (Spiker et al., 1978; Kaufman and Hopkins, 1985) and the circum-arctic (Walter et al., 2007; Reyes and Cooke, 2011). The age of the lowermost dated sample in unit D of $8370 \pm 50 \mathrm{yr}$ BP falls in the period of a pronounced early Holocene climate warming in NW North America (McCulloch and Hopkins, 1966; Detterman, 1970; Ritchie et al., 1983; Kaufman et al., 2004), a time when thermokarst lake formation peaked in Alaska and other high latitude regions (Walter et al., 2007) and intense peatland formation occurred in Alaska (Jones and Yu, 2010). Our fossil record therefore gives us a clear picture of the environmental conditions in Central Beringia during a period of warm summer growing conditions.

The early Holocene thermokarst lake subsequently drained, possibly due to thermo-erosion, and a pingo formed, elevating all described sediment horizons above their original position (Fig. 12e). The formation of a pingo likely is also the cause for absence of younger deposits at the studied site.

\subsection{Fossil-based regional palaeoenvironmental reconstruction}

The pollen assemblage in unit A, PZ-Ia, corresponding to the oldest sediments of mid-Wisconsin age or older, suggests an environment similar to modern shrub birch-willow tundra. Assemblages of PZ-Ib and PZ-Ic, which represent the main part of unit A, record a different flora and vegetation, with PZ-Ib dominated by Picea and PZ-Ic by Betula, and other woody taxa such as Larix and Salix, also present.
There are relatively few pollen records from the mid-Wisconsin in Alaska, and they vary as to the degree to which boreal forest vegetation is indicated. In interior Alaska, sites such as Isabella Basin (Matthews, 1974b) and Harding Lake (Nakao et al., 1980) record relatively high values of conifer pollen and have been interpreted as representing forested conditions. However, a recent multi-proxy analysis of a 32 ka BP old turf sample from the Fox permafrost tunnel suggests spruce was not abundant on the landscape and that the local vegetation was dominated by graminoids (grass and sedge) along with birch, alder, and willow (Wooller et al., 2011). Differences among these records may be attributable to the complexity of MIS 3-climate (Stuiver and Grootes, 2000; Anderson and Lozhkin, 2001), difficulties in accurately dating events near the limits of the radiocarbon method, or to taphonomic differences between lacustrine and terrestrial localities. In northern and western Alaska, high values of spruce linked to the previous interglaciation (MIS 5) are recorded from Squirrel Lake (Berger and Anderson, 2000), Ahaliorak Lake (Brubaker et al., 1995) and Imuruk Lake (Conlinvaux, 1964; Shackleton, 1982), while the records from Squirrel and Ahaliorak indicate low (ca 5\%) spruce values in the mid-Wisconsin. Holocene studies point to the variable representation of Picea in pollen rain near its distributional limits (Ritchie and Lichti-Federovich, 1967; Ritchie, 1984; Hu et al., 1995, 2006). Furthermore, Larix pollen is so poorly distributed that its presence is generally taken as indicating trees growing locally (Lozhkin and Anderson, 2011). Given these findings, and the fact that the sediments are interpreted as terrestrial or those contributing to a developing thermokarst lake, and thus receiving largely local and extra-local pollen, we conclude it is possible that spruce and larch stands grew in the area at this time. The relative predominance of grasses and sedges compared with deciduous taxa that typically form modern shrub tundra (Betula, Alnus, Salix) suggests the mosaic was an open one, with tree stands within a grass-forb vegetation that included herb taxa such as Asterceae and Thalictrum. Numerous spores of coprophilous fungi (Sordaria, Podospora, Sporormiella) and of Glomus (an indicator of disturbed vegetation) indirectly reflect that herds of grazing and/or browsing animals (that is, members of the Pleistocene megafauna) may have been common during the PZ-Ib interval. The vegetation 

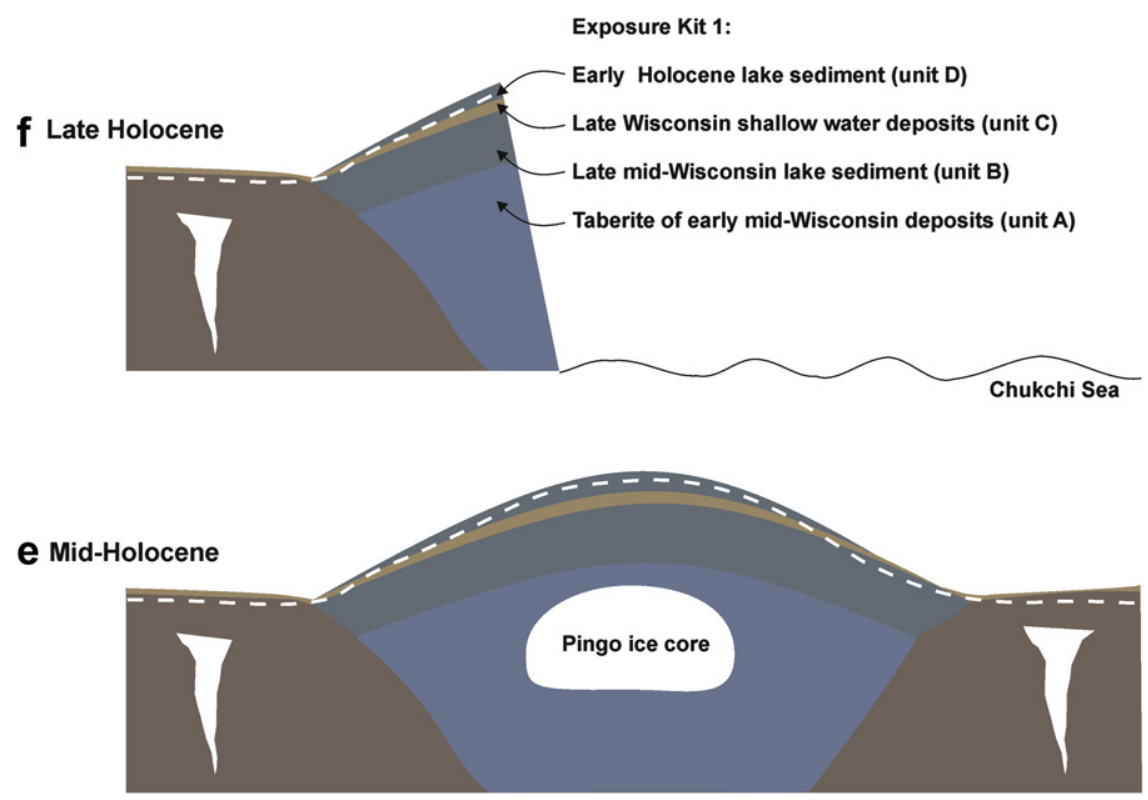

\section{d Early Holocene}

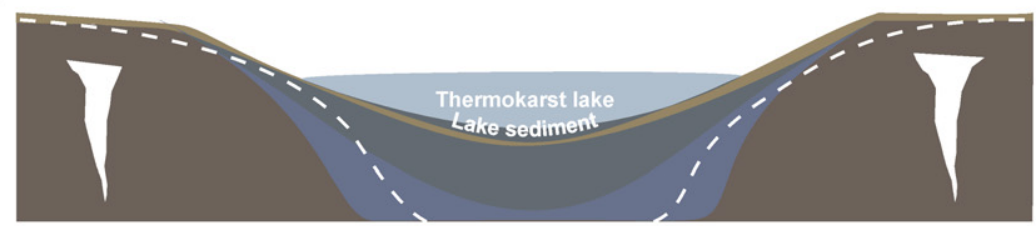

\section{Late Wisconsin}

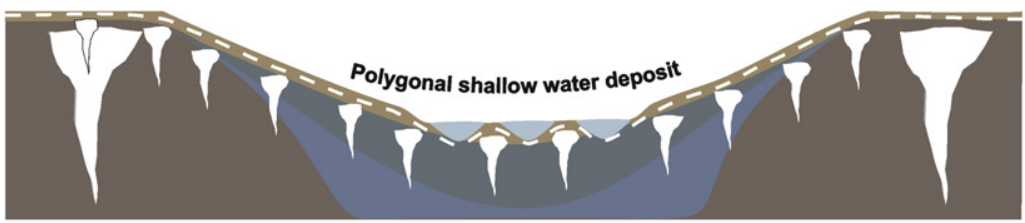

b Late mid-Wisconsin

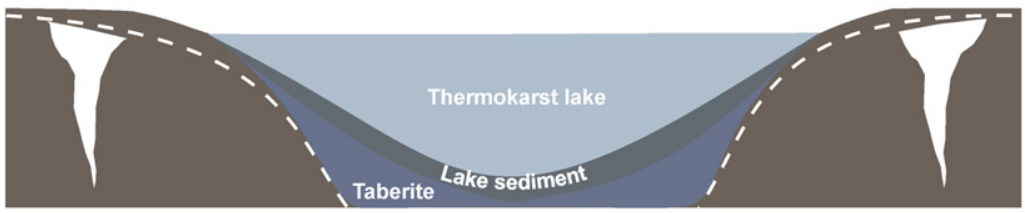

a Early mid-Wisconsin

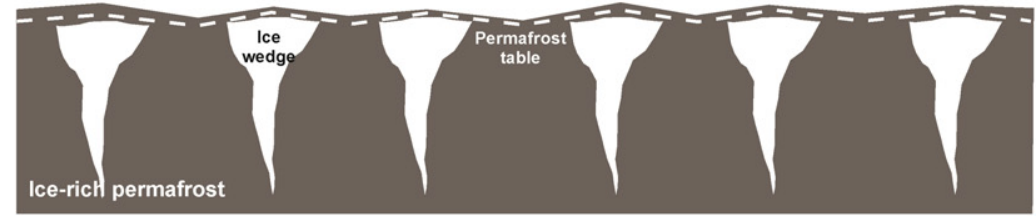

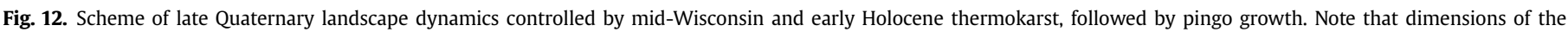
picture are rather schematic and not to scale.

community resembles neither Holocene ones nor those of the Last Interglaciation as far as the pollen assemblages are concerned, and it perhaps resulted from grazing pressure under conditions of temperature and moisture intermediate between interglacial and full stadial conditions.
The upper part of PZ-Ib and all of PZ-Ic correlate with the thermokarst sediments of unit $B(10.0-12.2 \mathrm{~m}$ a.s.l.), which is also dated to the mid-Wisconsin. A change occurs upwards to less conifer pollen and higher birch pollen, suggesting a decline in conifer cover. However, Larix pollen is present intermittently, suggesting the 
persistence of some larch trees near the site. The uppermost part of unit B is represented by PZ-II, which is dominated by a herbaceous pollen flora with some willow and birch, indicating tundra vegetation and a regional cooling. All considered macrofossil samples contain numerous remains of various aquatic vascular plants and algae (e.g. Myriophyllum spicatum, Hippuris vulgaris, Chara oospores), supporting the interpretation of a lake at the site.

Unit C is correlated with PZ-III. Pollen assemblages dominated by grass, sedge, and Asteraceae, plus the virtual absence of Sphagnum spores (which are intermittently present in the underlying unit B sediments), reflect colder and drier climate conditions. The unit probably dates to the LGM, based on a radiocarbon date of $18,950 \pm 110 \mathrm{yr}$ BP. The pollen assemblage of sample Kit 1-18, radiocarbon-dated to $14,330 \pm 25 \mathrm{yr} \mathrm{BP}$, and probably related to slumping of younger material into older (that of unit $B$ ) via an ice wedge cast, is dominated by pollen of Poaceae, Salix, Cyperaceae, Brassicaceae and spores of Equisetum. Such a spectrum is typical of the LGM and early Lateglacial herb pollen zone of the region.

Unit D is represented by PZ-IV. Betula and Ericales dominate, and in combination with the dated spruce macrofossil and the abundant Ericaceae macroremains, indicate that forest shrub tundra, evidently with at least scattered spruce trees and numerous ericaceous taxa characterised the area during the early-Holocene interval of extreme relative warmth.

The basal sediments of the lake that formed in the early Holocene (see above) are represented by macrofossil sample Kit 1-3, which is AMS radiocarbon-dated to $8370 \pm 50 \mathrm{yr}$ BP. The sample contains exceptionally rich, well preserved plant macrofossils. Pollen and macro plant remains indicate a birch dominated vegetation. Such an indication is supported from other studies in NW Alaska (Anderson, 1985, 1988; Ager, 2003). The plant cover was in general similar in composition to the recent vegetation. Characteristic floral elements were, like today, A. polifolia, E. nigrum, $L$. palustre, B. nana/glandulosa, and O. microcarpus. However, the lake and its environs supported several extralimital plant species that are distributed farther inland today: the aquatic and marshland taxa Ci. mackenzieana, P. alpinus ssp. tenuifolius, P. gramineus, P. praelongus, Ca. hermaphroditica, Utricularia intermedia and $\mathrm{Ce}$. demersum and the woody species Ch. calyculata and Picea sp.

Hygro- and hydrophilic rhizopod species of the genera Difflugia, Lagenodifflugia, and Centropyxis found in the uppermost unit D (Fig. 10) point to generally wet conditions, while the presence of sphagnophilic T. arcula, H. petricola, and $N$. tincta in sample Kit 1-2 indicates boggy conditions.

\subsection{Warm summers on the northern Seward Peninsula during the early-Holocene Thermal Maximum}

The numerous remains of boreal aquatic plants indicate a mean temperature of the warmest month above $13{ }^{\circ} \mathrm{C}$ during earlyHolocene time. Most of the extralimital aquatic species have high demands on temperature during the growing season. The occurrence of fruits of $\mathrm{Ce}$. demersum is especially remarkable since that species in Alaska occurs today frequently in the interior, although it has also been sighted on the North Pacific coast and in the Noatak valley to the north of the Seward Peninsula (Hultén, 1968; Les, 1986; Cody, 1996; GBIF, 2011). The plant mainly reproduces by vegetative fragmentation and requires for fruiting water temperatures above $25{ }^{\circ} \mathrm{C}$ (Mai, 1985, 1995). Mai (1995) states the northern distribution limit of Ce. demersum in Europe is correlated with the $18{ }^{\circ} \mathrm{C}$ July isotherm. In Alaska Ce. demersum grows at sites significantly cooler than $18{ }^{\circ} \mathrm{C}$ mean July temperature. However, the detection of well preserved fruits of Ce. demersum indicates that summer conditions considerably warmer than present occurred temporarily in the study area during the early Holocene. That Picea, which has a summer temperature requirement consistent with the other indicators of summer warmth, was present, but not abundant, raises questions as to the nature of the early Holocene climate, which was unlikely to be analogous to that of today, given differences in geography and insolation.

The timing of this warm period at the study site is in agreement with the early Holocene warm period identified previously by other workers in northern and northwestern Alaska (McCulloch and Hopkins, 1966; Detterman, 1970; Nelson and Carter, 1987; Mann et al., 2010) as well as Northwest Canada (Ritchie et al., 1983). In contrast to the work of Kaufman et al. (2004), who reconstructed a very early HTM culminating before $12 \mathrm{ka}$ cal BP and already ending ca $11 \mathrm{ka}$ cal BP, the dating of the HTM-representing sample Kit $1-3$, coincides well with the early Holocene warming peak around $9.2 \mathrm{ka}$ cal BP in Alaska. It is likely that summer warming, driven primarily by high summer insolation (Bartlein et al., 1991; Kaufman et al., 2004) was amplified locally by higher continentality as the site was distant from the palaeo-coastline of the transgressing Chukchi Sea. Today, coastal sites are noticeably cooler than inland areas due to the proximity of the ocean.

\subsection{Spruce and early-Holocene treeline in Northwest Alaska}

A macro remain of Picea sp. AMS-dated to $8250 \pm 100 \mathrm{yr}$ BP (9012-9462 yr cal BP) is evidence of the local presence of spruce in the Kitluk area during the early Holocene Thermal Maximum. This spruce twig is currently the only verified and dated spruce macrofossil from the early Holocene in western Alaska. The spruce wood reported in McCulloch and Hopkins (1966) was later retracted by Hopkins et al. (1981). While slender evidence for the presence of spruce, the Picea twig is clearly identifiable as such, and the date on the twig itself precludes the possibility of its being reworked from older sediments into the newly forming earlyHolocene thaw lake. The twig is also unlikely to be from driftwood as sea level was at least $10 \mathrm{~m}$ (McManus and Creager, 1984) or possibly as much as $20 \mathrm{~m}$ (Manley, 2002) below modern and the shoreline thus several kilometres seaward from the pingo.

Since the publication of Hopkins et al. (1981), which reported that no spruce date to the full glacial period, most workers have assumed that spruce did not survive the LGM. However, more recent work by Anderson et al. $(2006,2011)$ report phylogeographic evidence of possible local Beringian spruce populations, which reintroduces the notion of a glacial refugium. Brubaker et al. (2005) suggest that spruce pollen values during the LGM and Lateglacial, while low, may nevertheless indicate restricted spruce populations. Ritchie et al. (1983) report spruce needles from the Tuktoyaktuk Peninsula as early as $11.5 \mathrm{ka}$ BP and a white spruce log also from the Tuktoyaktuk Peninsula is dated to about 13 ka BP (Hopkins et al., 1981). In addition, a time-transgressive pattern of increased pollen values trending westward from northwestern Canada to central and southern Alaska indicate a major expansion of spruce about 9 ka BP (Brubaker et al., 2005). Pollen records from western Alaska, in which increased spruce values typically do not occur until 6-5 ka BP or later (Anderson, 1985, 1988; Hu et al., 1995; Ager, 2003), have been interpreted to represent the later westward migration of these central Alaskan and Canadian populations.

Low pollen values in western Alaska records in the early Holocene, including ours, suggest spruce was uncommon and/or barely producing pollen, but there are situations, such as parts of the modern boreal treeline, where local Picea pollen production is extremely low (Hicks, 2006). However, Colinvaux (1967, 1981) provides compelling evidence from St. Paul Island that spruce populations may have been present on the Bering Land Bridge (Fig. 1); he reports a sustained period of high spruce values in the Lateglacial and early Holocene, which he interprets to represent the 
local presence of spruce on the southern edge of the land bridge. These early western records suggest the presence of Picea in cryptic refugia (Stewart and Lister, 2001). Other pollen evidence from western Alaska is equivocal (Fig. 1). There is a period of low (ca 3\%) but consistent spruce influx in the early Holocene at Burial Lake at around $10 \mathrm{ka}$ BP (Abbott et al., 2010), while at Squirrel Lake (Anderson, 1988) and North Killeak Maar (Charron, 1995) the values throughout the Lateglacial and early Holocene are low and sporadic (about 1\%), rather like the record at the Kitluk pingo.

Implications are that spruce spread from a western (land bridge) refugium with the early Holocene warming, but it failed to expand (and possibly even failed to persist) in western Alaska. This may have been because the populations were overtaken by the transgression and the major climate changes (especially cooler summers) that would have occurred with coastal retreat across the land bridge, before they were able to expand further inland. One feature of the early Holocene climate was high seasonality, and, until the transgression, the region was also highly continental, making the survival of evergreen conifers more difficult, as lack of available moisture may have been a major stress (Hogg, 1994; Barber et al., 2000). Subsequently, spruce populations in central Alaska expanded in a westerly direction during moister but cooler conditions, reaching the current treeline, which still lies to the east of the Kitluk site.

There is evidence that tree-sized deciduous woody vegetation was more abundant in northwestern Alaska during the early Holocene than today. Finds of tree-sized wood suggest that phenotypically plastic taxa such as some willows and shrub birch (and its hybrids with tree birch) were able to form deciduous forest vegetation in the early Holocene (Edwards et al., 2005). McCulloch and Hopkins (1966) report on finds of beaver-gnawed tree-size logs of poplar and willow in early Holocene sediments on the nearby Baldwin Peninsula and in the central Seward Peninsula: in all, eight radiocarbon dates of wood from various locations point to a warmer than present period at around 10-8.3 ka BP (Hopkins et al., 1981). Furthermore, the occurrence at Kitluk of the freshwater bryozoan $C$. mucedo indicates boreal climate conditions sufficient for the growth of Betula forests (Økland and Økland, 2000; Vorren et al., 2009). Other evidence of extralimital tree growth in the early Holocene comes from Nelson and Carter (1987) and Mann et al. (2010) who report multiple finds of fossil Populus balsamifera logs in today's treeless alluvial plains of the Alaskan North Slope foothills, all radiocarbon dated to 11.6-9.3 cal ka BP. For Seward Peninsula, McCulloch and Hopkins (1966) conclude that with further sea level rise and the advance of the shoreline eastwards after $8 \mathrm{ka}$ BP the Kotzebue Sound region became increasingly maritime, rendering conditions unsuitable for tree growth.

\section{Conclusions}

Our study presents the first radiocarbon-dated evidence for mid-Wisconsin interstadial thermokarst lake development in central Beringia, indicating there have been complex landscape interactions with cyclic permafrost aggradation and degradation (thermokarst) over stadial-interstadial as well as glacialinterglacial time periods. We confirm previous observations of an early-Holocene warm period in NW North America. A number of extralimital fossil plant remains from the Kitluk site indicate that this early-Holocene Thermal Maximum was considerably warmer than present, at least for a short period. The remarkable find of a spruce macrofossil (twig) radiocarbon-dated to $8250 \pm 100 \mathrm{yr} \mathrm{BP}$ far beyond the presumed early-Holocene limits of spruce suggests the presence of refugia in the central Beringia shelf region and requires a re-evaluation of the current hypotheses of timing and direction of spruce recolonization of post-glacial Alaska. It seems, however, that an increasing maritime influence due to rising
Holocene sea level may have resulted in the extinction of western spruce populations.

\section{Acknowledgements}

The fieldwork was financially supported by the National Science Foundation (NSF grant $\mathcal{N}$ o 0732735) and the Deutsche Forschungsgemeinschaft (DFG grants $\mathcal{N}$ o SCHI 530/7-1, WE 4390/2-1 and KI 849/2-1). Additional support was provided from NASA Carbon Cycle Sciences grant NNX08AJ37G. We thank Hanno Meyer and Georg Schwamborn for help in the field, and Helga Kemnitz (GeoForschungsZentrum Potsdam, Germany) who helped with SEM photography. We thank Katey Walter Anthony (WERC, University of Alaska, Fairbanks, USA), the CH2M Hill Polar Services Fairbanks Office staff as well as Curtis Nayokpuk and Fred Goodhope from Shishmaref for logistical support. We acknowledge US National Park Service permitting to work in Bering Land Bridge National Preserve. Two reviewers of the paper (Anonymous and Thomas D. Hamilton, USGS Alaska Science Center, Anchorage, USA) greatly helped by their suggestions to improve the final publication of this study.

\section{Appendix. Supplementary material}

Supplementary material associated with this article can be found, in the online version, at doi:10.1016/j.quascirev.2012.01.027.

\section{References}

Abbott, M.B., Edwards, M.E., Finney, B.P., 2010. A 40,000-yr record of environmental change from Burial Lake in Northwest Alaska. Quaternary Research 74, $156-165$.

Ager, T.A., 2003. Late Quaternary vegetation and climate history of the central Bering land bridge from St. Michael Island, western Alaska. Quaternary Research 60, 19-32.

Alaska Climate Research Center, 2008. Online source: http://climate.gi.alaska.edu.

Anderson, P.M., 1985. Late Quaternary vegetational change in the Kotzebue sound area, northwestern Alaska. Quaternary Research 24, 307-321.

Anderson, P.M., 1988. Late Quaternary pollen records from the Kobuk and Noatak River drainages, northwestern Alaska. Quaternary Research 29, 263-276.

Anderson, P.M., Brubaker, L.B., 1986. Modern pollen assemblages from northern Alaska. Review of Palaeobotany and Palynology 46, 273-291.

Anderson, P.M., Lozhkin, A.V., 2001. The Stage 3 interstadial complex (Karginskii/ middle Wisconsinan interval) of Beringia: variations in paleoenvironments and implications for paleoclimatic interpretations. Quaternary Science Reviews 20, 93-125.

Anderson, P.M., Edwards, M.E., Brubaker, L.B., 2004. Results and paleoclimatic implications of 35 years of paleoecological research in Alaska. In: Gillespie, A.R. Porter, S.C., Atwater, B.F. (Eds.), The Quaternary Period in the United States Development in Quaternary Science. Elsevier, New York, pp. 427-440.

Anderson, L.L., Hu, F.S., Nelson, D.M., Petit, R.J., Paige, K.N., 2006. Ice-age endurance: DNA evidence of a white spruce refugium in Alaska. Proceedings of the Academy of Sciences 103, 12447-12450.

Anderson, L.L., Hu, F.-S., Paige, K.N., 2011. Phylogeographic history of white spruce during the Last Glacial Maximum: uncovering cryptic refugia. Journal of Heredity 102, 207-216.

Andreev, A.A., Schirrmeister, L., Tarasov, P.E., Ganopolski, A., Brovkin, V., Siegert, C., Wetterich, S., Hubberten, H.-W., 2011. Vegetation and climate history in the Laptev Sea region (Arctic Siberia) during late Quaternary inferred from pollen records. Quaternary Science Reviews 30, 2182-2199.

Barber, V.A., Juday, G.P., Finney, B.P., 2000. Reduced growth of Alaskan white spruce in the twentieth century from temperature-induced drought stress. Nature 405, 668-673.

Bartlein, P.J., Anderson, P.M., Edwards, M.E., McDowell, P.F., 1991. A framework for interpreting paleoclimatic variations in eastern Beringia. Quaternary International $10-12,73-83$.

Begét, J., Mason, O., Anderson, P., 1992. Age, extent and climatic significance of the c. 3400 BP Aniakchak Tephra, Western Alaska, USA. The Holocene 2, 51-56.

Begét, J.E., Hopkins, D.M., Charron, S.D., 1996. The largest known maars on Earth, Seward Peninsula, Northwest Alaska. Arctic 49, 62-69.

Berger, G.W., Anderson, P.M., 2000. Extending the geochronometry of Arctic lake cores beyond the radiocarbon limit by using thermoluminescence. Journal of Geophysical Research 105, 15439-15455.

Berggren, G., 1969. Atlas of Seeds and Fruits of Northwest-European Plant Species with Morphological Descriptions: Part 2. Cyperaceae. Swedish Natural Science Research Council, Stockholm. 
Berglund, B.E., Ralska-Jasiewiczowa, M., 1986. Pollen analysis and pollen diagrams. In: Berglund, B.E. (Ed.), Handbook of Holocene Palaeoecology and Palaeohydrology. Interscience, New York, pp. 455-484.

Beug, H.-J., 2004. Leitfaden der Pollenbestimmung für Mitteleuropa und angrenzende Gebiete. Verlag Dr. Friedrich Pfeil, München.

Bobrov, A.E., Kuprianova, L.A., Litvinseva, M.V., Tarasevich, V.F., 1983. Sporae Pteridophytorum et Pollen Gymnospermarum Monocotyledonearumque Florae partis Europaeae URSS. Nauka, Leningrad.

Brigham-Grette, J., 2001. New perspectives on Beringian Quaternary paleogeography, stratigraphy, and glacial history. Quaternary Science Reviews 20, $15-24$.

Brubaker, L.B., Anderson, P.M., Oswald, W.W., 1995. A new pollen record from Ahaliorak Lake, North Slope, Alaska. In: Third Annual Paleoclimates from Arctic Lakes and Estuaries (PALE) PI Abstracts Volume, Boulder CO, pp. 54-57.

Brubaker, L.B., Anderson, P.M., Edwards, M.E., Lozhkin, A.V., 2005. Beringia as a glacial refugium for boreal trees and shrubs: new perspectives from mapped pollen data. Journal of Biogeography 32, 833-848.

Calkin, P.E., Kaufman, D.S., Przybyl, B.J., Whitford, W.B., Peck, B.J., 1998. Glacier regimes, periglacial landforms, and Holocene climate change in the Kigluaik Mountains, Seward Peninsula, Alaska, U.S.A. Arctic and Alpine Research 30, 154-165.

Charron, S.D., 1995. Surficial mapping of the Cape Espenberg-Devil Mountain Region and lakecore analyses from North Killeak Lake, Bering Land Bridge National Preserve, Western Alaska, Unpublished Masters thesis, University of Massachusetts.

Cody, W.J., 1996. Flora of the Yukon Territory. NRC Research Press, Ottawa.

Colinvaux, P.A., 1964. The environment of the Bering land bridge. Ecological Monographs 34, 297-329.

Colinvaux, P.A., 1967. Bering Land Bridge: evidence of spruce in late-Wisconsin times. Science 156, 380-383.

Colinvaux, P.A., 1981. Historical ecology in Beringia: the south land bridge coast at St. Paul Island. Quaternary Research 16, 18-36.

Delorme, L.D., 1968. Pleistocene freshwater Ostracoda from Yukon, Canada. Canadian Journal of Zoology 46, 253-266.

Detterman, R.L., 1970. Early Holocene warm interval in northern Alaska. Arctic 23, $130-132$.

Edwards, M.E., Armbruster, W.S., 1989. A tundra-steppe transition on Kathul Mountain, Alaska, USA. Arctic, Antarctic and Alpine Research 21, 296-304.

Edwards, M.E., Brubaker, L.B., Lozhkin, A.V., Anderson, P.M., 2005. Structurally novel biomes: a response to past warming in Beringia. Ecology 86, 1696-1703.

Elias, S.A., Short, S.K., Nelson, C.H., Birks, H.H., 1996. Life and times of the Bering land bridge. Nature 382, 60-63.

Elias, S.A., Short, S.K., Birks, H.H., 1997. Late Wisconsin environments of the Bering Land Bridge. Palaeogeography, Palaeoclimatology, Palaeoecology 136, 293-308.

Elias, S.A., 2000. Late Pleistocene climates of Beringia, based on analysis of fossil beetles. Quaternary Research 53, 229-235.

Elias, S.A., 2001. Mutual climatic range reconstructions of seasonal temperatures based on Late Pleistocene fossil beetle assemblages in Eastern Beringia. Quaternary Science Reviews 20, 77-91.

Fægri, K., Iversen, J., 1989. In: Fægri, K., Kaland, P.E., Krzywinski, K. (Eds.), Textbook of Pollen Analysis, fourth ed. John Wiley \& Sons, Chichester, pp. 69-89.

Flemal, R.C., 1976. Pingos and pingo scars: their characteristics, distribution, and utility in reconstructing former permafrost environments. Quaternary Research 6, 37-53.

Forcino, F.L., Richards, E.J., Leighton, L.R., Chojnacki, N., Stafford, E.S., 2012. The sensitivity of paleocommunity sampling strategy at different spatiotemporal scales. Palaeogeography, Palaeoclimatology, Palaeoecology 313-314, 246-253.

Froese, D.G., Westgate, J.A., Reyes, A.V., Enkin, R.J., Preece, S.J., 2008. Ancient permafrost and a future, warmer Arctic. Science 321, 1648.

GBIF, 2011. Global Biodiversity Information Facility. Online source: http://data.gbif.org.

Goetcheus, V.G., Birks, H.H., 2001. Full-glacial upland tundra vegetation preserved under tephra in the Beringia National Park, Seward Peninsula, Alaska. Quaternary Science Reviews 20, 135-147.

Goetcheus, V.G., Hopkins, D.M., Edwards, M.E., Mann, D.H., 1994. Window on the Bering Land Bridge: a 17,000 yr BP paleosurface on the Seward Peninsula, Alaska. Current Research in the Pleistocene 11, 131-132.

Goslar, T., Czernik, J., Goslar, E., 2004. Low-energy 14C AMS in Poznan radiocarbon Laboratory, Poland. Nuclear Instruments and Methods in Physics Research B 223-224, 5-11.

Grimm, E., 1991. Tilia and Tiliagraph. Illinois State Museum, Springfield, IL, USA.

Grimm, E., 2004. Tilia, Tiliagraph and TGView 2.0.2. Illinois State Museum, Springfield, IL, USA.

Grosse, G., Jones, B.M., 2011. Spatial distribution of pingos in Northern Asia. The Cryosphere 5, 13-33.

Grosse, G., Schirrmeister, L., Siegert, C., Kunitsky, V.V., Slagoda, E.A., Andreev, A.A., Dereviagyn, A.Y., 2007. Geological and geomorphological evolution of a sedimentary periglacial landscape in Northeast Siberia during the Late Quaternary. Geomorphology 86, 25-51.

Hammond, T., Yarie, J., 1996. Spatial prediction of climatic state factor regions in Alaska. Ecoscience 3, 490-501.

Hicks, S., 2006. When no pollen does not mean no trees. Vegetation History and Archaeobotany 15, 253-261.

Höfle, C., Ping, C.-L., 1996. Properties and soil development of late-Pleistocene paleosols from Seward Peninsula, northwest Alaska. Geoderma 71, 219-243.
Höfle, C., Edwards, M.E., Hopkins, D.M., Mann, D.H., 2000. The full-glacial environment of the northern Seward Peninsula, Alaska, reconstructed from the 21,500-year-old Kitluk paleosol. Quaternary Research 53, 143-153.

Hogg, E.H., 1994. Climate and the southern limit of the western Canadian boreal forest. Canadian Journal of Forest Research 24, 1835-1845.

Hopkins, D.M., 1959a. Cenozoic history of the Bering Land Bridge. Science 129, 1519-1528.

Hopkins, D.M., 1959b. History of Imuruk Lake, Seward Peninsula, Alaska. Geological Society of America Bulletin 70, 1033-1046.

Hopkins, D.M., 1963. Geology of the Imuruk Lake Area Seward Peninsula, Alaska. Geological Survey Bulletin 141-C, 1-101.

Hopkins, D.M. (Ed.), 1967. The Bering Land Bridge. Stanford University Press, Stanford.

Hopkins, D.M., 1973. Sea level history in Beringia during the past 250,000 years. Quaternary Research 3, 520-540.

Hopkins, D.M., 1982. Aspects of the paleogeography of Beringia during the late Pleistocene. In: Hopkins, D.M., Matthews Jr., J.V., Schweger, C.E., Young, S.B. (Eds.), Paleoecology of Beringia. Academic Press, New York, pp. 3-28.

Hopkins, D.M., Kidd, J.G., 1988. Thaw lake sediments and sedimentary environments. In: 5th International Permafrost Conference. Tapir, Trondheim, pp. 790-795.

Hopkins, D.M., Karlstrom, T.N.V., Black, R., Pewe, T.L., Fernold, A.T., Muller, E.H., 1955. Permafrost and Ground Water in Alaska. In: U.S. Geological Survey Professional Paper 264, 1-70 pp.

Hopkins, D.M., MacNeil, F.S., Merklin, R.L., Petrov, O.M., 1965. Quaternary correlations across Bering Strait. Science 147, 1107-1114.

Hopkins, D.M., Giterman, R.E., Matthews, J.V., 1976. Interstadial mammoth remains and associated pollen and insect fossils, Kotzebue Sound area, northwestern Alaska. Geology 4, 169-172.

Hopkins, D.M., Smith, P.A., Matthews, J.V., 1981. Dated wood from Alaska and the Yukon: implications for forest refugia in Beringia. Quaternary Research 15, 217-249.

Hu, F.S., Brubaker, L.B., Anderson, P.M., 1995. Postglacial vegetation and climate change in the northern Bristol Bay region, southwestern Alaska. Quaternary Research 43, 382-392.

Hu, F.S., Brubaker, L.B., Gavin, D.G., Higuera, P.E., Lynch, J.A., Rupp, T.S., Tinner, W., 2006. How climate and vegetation influence the fire regime of the Alaskan boreal-forest biome: the Holocene perspective. Mitigation and Adaptation Strategies for Global Change 11, 829-846.

Hubberten, H.-W., Andreev, A., Astakhov, V.I., Demidov, I., Dowdeswell, J.A., Henriksen, M., Hjort, C., Houmark-Nielsen, M., Jakobsson, M., Kuzmina, S. Larsen, E., Lunkka, J.P., Lysa, A., Mangerud, J., Möller, P., Saarnisto, M., Schirrmeister, L., Sher, A.V., Siegert, C., Siegert, M.J., Svendsen, J.I., 2004. The periglacial climate and environment in northern Eurasia during the last glaciation. Quaternary Science Reviews 23, 1333-1357.

Hultén, E., 1937. Outline of the History of Arctic and Boreal Biota during the Quaternary Period. Bokförlags Aktiebolaget Thule, Stockholm.

Hultén, E., 1968. Flora of Alaska and Neighboring Territories, A Manual of Vascular Plants. Stanford University Press, Stanford.

Hyvärinen, H., Ritchie, J.C., 1975. Pollen stratigraphy of Mackenzie pingo sediments N.W.T., Canada. Arctic and Alpine Research 7, 261-272.

Jessen, K., 1955. Key to subfossil Potamogeton. Botanisk Tidsskrift 52, 1-7.

Jones, M.C., Yu, Z., 2010. Rapid deglacial and early Holocene expansion of peatlands in Alaska. Proceedings of the National Academy of Sciences 107, 7347-7352.

Jones, M., Grosse, G., Arp, C.D., Jones, M.C., Walter Anthony, K.M., Romanovsky, V.E., 2011. Modern thermokarst lake dynamics in the continuous permafrost zone, northern Seward Peninsula, Alaska. Journal of Geophysical Research 116 G00M03.

Jones, B.M., Grosse, G., Hinkel, K.M., Arp, C.D., Walker, S., Beck, R.A., Galloway, J.P., 2012. Assessment of pingo distribution and morphometry using an IfSAR derived DSM, western Arctic Coastal Plain, northern Alaska. Geomorphology 138 (1), 1-14.

Jordan, J.W., Mason, O.K., 1999. A 5000 year record of intertidal peat stratigraphy and sea level change from northwest Alaska. Quaternary International 60 37-47.

Jorgenson, M.T., Yoshikawa, K., Kanevskiy, M., Shur, Y.L., Romanovsky, V., Marchenko, S., Grosse, G., Brown, J., Jones, B., 2008. Permafrost characteristics of Alaska. In: Kane, D., Hinkel, K. (Eds.), Proceedings of the Ninth International Conference on Permafrost. University of Alaska, Fairbanks, AK, pp. 121-122.

Kanevskiy, M., Shur, Y., Fortier, D., Jorgenson, M.T., Stephani, E., 2011. Cryostratigraphy of late Pleistocene syngenetic permafrost (yedoma) in northern Alaska, Itkillik River exposure. Quaternary Research 75, 584-596.

Kaufman, D.S., Hopkins, D.M., 1985. Late Cenozoic Radiometric Dates, Seward and Baldwin Peninsulas, and Adjacent Continental Shelf, Alaska. In: US Geological Survey Open-File Report, 85-374 pp.

Kaufman, D.S., Hopkins, D.M., 1986. Glacial history of the Seward Peninsula. In: Hamilton, T.D., Reed, K.M., Thorson, R.M. (Eds.), Glaciation of Alaska: The Geologic Record. Alaska Geological Society, Anchorage, pp. 51-78.

Kaufman, D.S., Manley, W.F., 2004. Pleistocene Maximum and Late Wisconsin glacier extents across Alaska, U.S.A. In: Ehlers, J., Gibbard, P.L. (Eds.), Quaternary Glaciations - Extent and Chronology, Part II, North America. Developments in Quaternary Science, vol. 2b. Elsevier, Amsterdam, pp. 9-27.

Kaufman, D.S., Ager, T.A., Anderson, N.J., Anderson, P.M., Andrews, J.T., Bartlein, P.J., Brubaker, L.B., Coats, L.L., Cwynar, L.C., Duvall, M.L., Dyke, A.S., Edwards, M.E., Eisner, W.R., Gajewski, K., Geirsdóttir, A., Hu, F.S., Jennings, A.E., Kaplan, M.R. 
Kerwin, M.W., Lozhkin, A.V., MacDonald, G.M., Miller, G.H., Mock, C.J., Oswald, W.W., Otto-Bleisner, B.L., Porinchu, D.F., Rühland, K., Smol, J.P. Steig, E.J., Wolfe, B.B., 2004. Holocene thermal maximum in the western Arctic $\left(0-180^{\circ} \mathrm{W}\right)$. Quaternary Science Reviews 23, 529-560.

Kienast, F., Tarasov, P., Schirrmeister, L., Grosse, G., Andreev, A.A., 2008. Continental climate in the East Siberian Arctic during the last interglacial: implications from palaeobotanical records. Global and Planetary Change 60, 535-562.

Kupriyanova, L.A., Alyoshina, L.A., 1972. In: Pollen and Spores of Plants from the Flora of European Part of USSR, vol. I. Academy of Sciences USSR, Komarov Botanical Institute, Leningrad (in Russian).

Kupriyanova, L.A., Alyoshina, L.A., 1978. Pollen and Spores of Plants from the Flora of European Part of USSR. Academy of Sciences USSR, Komarov Botanical Institute, Leningrad (in Russian).

Kuzmina, S., Elias, S., Matheus, P., Storer, J.E., Sher, A., 2008. Paleoenvironmental reconstruction of the Last Glacial Maximum, inferred from insect fossils from a tephra buried soil at Tempest Lake, Seward Peninsula, Alaska. Palaeogeography, Palaeoclimatology, Palaeoecology 267, 245-255.

Les, D.H., 1986. The phytogeography of Ceratophyllum demersum and C. echinatum (Ceratophyllaceae) in glaciated North America. Canadian Journal of Botany 64 498-509.

Lozhkin, A.V., Anderson, P.M., 2011. Forest or no forest: implications of the vegetation record for climatic stability in Western Beringia during Oxygen Isotope Stage 3. Quaternary Science Reviews 30, 2160-2181.

Mackay, J.R., 1962. Pingos of the Pleistocene Mackenzie Delta area. Geographica Bulletin 18, 21-63.

Mackay, J.R., 1985. Pingo ice of the western Arctic coast, Canada. Canadian Journal of Earth Sciences 22, 1452-1464.

Mackay, J.R., 1986. Growth of Ibyuk Pingo, western Arctic coast, Canada, and some implications for environmental reconstructions. Quaternary Research 26 $68-80$.

Mai, D.H., 1985. Development of the water plant and swamp associations of Europe from the Cretaceous to the Quaternary. Flora 176, 449-511.

Mai, D.H., 1995. Tertiäre Vegetationsgeschichte Europas. Methoden und Ergebnisse. (Tertiary vegetation history of Europe. Methods and results). Gustav Fischer Verlag, Jena.

Manley, W.F., 2002. Postglacial Flooding of the Bering Land Bridge: A Geospatial Animation. INSTAAR, University of Colorado. Online source: http://instaar. colorado.edu/QGISL/bering_land_bridge.

Manley, W.F., Daly, C., 2005. Alaska Geospatial Climate Animations of Monthly Temperature and Precipitation. INSTAAR, University of Colorado. Online source: http://instaar.colorado.edu/QGISL/AGCA.

Mann, D.H., Groves, P., Reanier, R.E., Kunz, M.L., 2010. Floodplains, permafrost cottonwood trees, and peat: what happened the last time climate warmed suddenly in arctic Alaska? Quaternary Science Reviews 29, 3812-3830.

Matthews Jr., J.V., 1974a. Quaternary environments at Cape Deceit (Seward Peninsula, Alaska) - evolution of a tundra ecosystem. Geological Society of America Bulletin 85, 1353-1384.

Matthews, J.V., 1974b. Wisconsin environment of interior Alaska: pollen and macrofossil analysis of a 27 meter core from the Isabella Basin (Fairbanks, Alaska). Canadian Journal of Earth Sciences 11, 828-841.

McCulloch, D., Hopkins, D., 1966. Evidence for an early recent warm interval in Northwestern Alaska. Geological Society of America Bulletin 77, 1089-1108.

McDowell, P.F., Edwards, M.E., 2001. Evidence of Quaternary climatic variations in a sequence of loess and related deposits at Birch Creek, Alaska: implications for the Stage 5 climatic chronology. Quaternary Science Reviews 20, 63-76.

McManus, D.A., Creager, J.S., 1984. Sea-level data for parts of the Bering-Chukchi shelves of Beringia from 19,000 to 10,000 14C yr BP. Quaternary Research 21, 317-325.

Meisch, C., 2000. Freshwater Ostracoda of Western and Central Europe. Spektrum Akademischer Verlag, Heidelberg, Berlin.

Meyer, H., Schirrmeister, L., Yoshikawa, K., Opel, T., Wetterich, S., Hubberten, H.-W. Brown, J., 2010. Permafrost evidence for severe winter cooling during the Younger Dryas in northern Alaska. Geophysical Research Letters 37, L03501.

Muhs, D.R., Ager, T.A., Bettis, A.E.I., McGeehin, J.P., Been, J., Beget, J.E., Pavich Milan, J., Stafford, T.W.J., Stevens, D.A.S.P., 2003. Stratigraphy and palaeoclimatic significance of Late Quaternary loess-palaeosol sequences of the Last Interglacial-Glacial cycle in central Alaska. Quaternary Science Reviews 22, 1947-1986.

Murton, J.B., 1996. Thermokarst-lake-basin sediments, Tuktoyaktuk Coastlands, western arctic Canada. Sedimentology 43, 737-760.

Murton, J.B., 2001. Thermokarst sediments and sedimentary structures, Tuktoyaktuk Coastlands, Western Arctic Canada. Global and Planetary Change 28 175-192.

Nakao, K., La Pierre, J., Ager, T.A., 1980. Climatic changes in Interior Alaska. In: Nakao, K. (Ed.), Climatic Changes in Interior Alaska. Department of Geophysics, Hokkaido University, Sapporo, pp. 16-23.

Nelson, R.E., Carter, L.D., 1987. Paleoenvironmental analysis of insects and extralimital Populus from an early Holocene site on the Arctic Slope of Alaska, U.S.A. Arctic and Alpine Research 19, 230-241.

Økland, K.A., Økland, J., 2000. Freshwater bryozoans (Bryozoa) of Norway: distribution and ecology of Cristatella mucedo and Paludicella articulata. Hydrobiologia $421,1-24$

Pewé, T.L., 1975. Quaternary Geology of Alaska. In: Geological Survey Professional Paper 835, 1-145 pp.
Raynolds, M.K., Walker, D.A., Maier, H.A., 2006. NDVI patterns and phytomass distribution in the circumpolar Arctic. Remote Sensing of Environment 102, 271-281.

Reille, M., 1992. Pollen et spores d'Europe et d'Afrique du nord. Laboratoire de Botanique historique et de Palynologie, Marseille.

Reille, M., 1995. Pollen et spores d'Europe et d'Afrique du nord, supplement 1. Laboratoire de Botanique historique et de Palynologie, Marseille.

Reille, M., 1998. Pollen et spores d'Europe et d'Afrique du nord, supplement 2. Laboratoire de Botanique historique et de Palynologie, Marseille.

Reimer, P.J., Baillie, M.G.L., Bard, E., Bayliss, A., Beck, J.W., Blackwell, P.G., Bronk Ramsey, C., Buck, C.E., Burr, G.S., Edwards, R.L., Friedrich, M., Grootes, P.M., Guilderson, T.P., Hajdas, I., Heaton, T.J., Hogg, A.G., Hughen, K.A., Kaiser, K.F., Kromer, B., McCormac, F.G., Manning, S.W., Reimer, R.W., Richards, D.A., Southon, J.R., Talamo, S., Turney, C.S.M., van der Plicht, J., Weyhenmeyer, C.E., 2009. IntCal09 and Marine09 radiocarbon age calibration curves, $0-50,000$ years cal BP. Radiocarbon 51, 1111-1150.

Reyes, A.V., Cooke, C.A., 2011. Northern peatland initiation lagged abrupt increases in deglacial atmospheric $\mathrm{CH}_{4}$. Proceedings of the National Academy of Sciences 108 (12), 4748-4753.

Ritchie, J.C., 1984. Past and Present Vegetation of the Far Northwest of Canada. University of Toronto Press, Toronto.

Ritchie, J.C., Lichti-Federovich, S., 1967. Pollen dispersal phenomena in ArcticSubarctic Canada. Review of Palaeobotany and Palynology 3, 255-266.

Ritchie, J.C., Cwynar, L.C., Spear, R.W., 1983. Evidence from north-west Canada for an early Holocene Milankovitch thermal maximum. Nature 305, 126-128.

Romanovskii, N.N., 1993. Basics of Cryogenesis in the Lithosphere. Moscow University Press, 335 pp. (in Russian).

Romanovskii, N.N., Hubberten, H.-W., Gavrilov, A.V., Tumskoy, V.E., Kholodov, A.L., 2004. Permafrost of the east Siberian Arctic shelf and coastal lowlands. Quaternary Science Reviews 23, 1359-1369.

Rupp, R.S., Chapin III, F.S., Starfield, A.M., 2001. Response of subarctic vegetation to transient climatic change on the Seward Peninsula in north-west Alaska. Global Change Biology 6, 541-555.

Santos, G.M., Southon, J., Griffin, S., Beaupre, S.R., Druffel, E.R., 2007. Ultra smallmass 14C-AMS sample preparation and analysis at the KCCAMS Facility. Nuclear Instruments and Methods in Physics Research B 259, 293-302.

Schirrmeister, L., Siegert, C., Kuznetsova, T. Kuzmina, S., Andreev, A., Kienast, F, Meyer, H., Bobrov, A., 2002. Paleoenvironmental and paleoclimatic records from permafrost deposits in the Arctic region of Northern Siberia. Quaternary International 89, 97-118.

Schirrmeister, L., Grosse, G., Kunitsky, V., Magens, D., Meyer, H., Dereviagin, A., Kuznetsova, T., Andreev, A., Babiy, O., Kienast, F., Grigoriev, M., Overduin, P.P., Preusser, F., 2008. Periglacial landscape evolution and environmental changes of Arctic lowland areas for the last 60,000 years (western Laptev Sea coast, Cape Mamontov Klyk). Polar Research 27, 249-272.

Shackleton, J., 1982. Environmental Histories from Whitefish and Imuruk Lakes, Seward Peninsula, Alaska. In: Institute of Polar Studies Report No. 76. Ohio State University, Columbus.

Sher, A.V., Kuzmina, S.A., Kuznetsova, T.V., Sulerzhitsky, L.D., 2005. New insights into the Weichselian environment and climate of the East Siberian Arctic, derived from fossil insects, plants, and mammals. Quaternary Science Reviews 24, 533-569.

Smith, A.J., Delorme, L.D., 2010. Chapter 19-Ostracoda. In: Thorp, J.H., Covich, A.P. (Eds.), Ecology and Classification of North American Freshwater Invertebrates (Aquatic Ecology). Elsevier, London, Burlington MA, San Diego CA, pp. 725-771.

Spiker, E., Kelley, L., Rubin, M., 1978. U.S. Geological Survey radiocarbon dates XIII. Radiocarbon 20, 139-156.

Staplin, F.L., 1963a. Pleistocene Ostracoda of Illinois. Part I. Subfamilies Candoninae, Cyprinae, general ecology, morphology. Journal of Paleontology 37, 758-797.

Staplin, F.L., 1963b. Pleistocene Ostracoda of Illinois. Part II. Subfamilies Cyclocyprinae, Cypridopsinae, Ilyocyprinae; families Darwinulidae and Cytheridae. Stratigraphic ranges and assemblage patterns. Journal of Paleontology 37, $1164-1203$.

Stewart, J.R., Lister, A.M., 2001. Cryptic northern refugia and the origins of the modern biota. Trends in Ecology and Evolution 16, 608-613.

Stockmarr, J., 1971. Tablets with spores used in absolute pollen analysis. Pollen et Spores 13, 615-621.

Stuiver, M., Grootes, P.M., 2000. GISP2 oxygen isotope ratios. Quaternary Research 53, 277-284.

Swain, F.M., 1963. Pleistocene Ostracoda from the Gubik formation, Arctic Coastal Plain, Alaska. Journal of Paleontology 37, 798-834.

van Everdingen, R. (Ed.), 1998. Multi-language Glossary of Permafrost and Related Ground-ice Terms. National Snow and Ice Data Center/World Data Center for Glaciology, Boulder CO. Revised in May 2005.

van Geel, B., 2001. Non-pollen palynomorphs. In: Smol, J.P., Birks, H.J.B., Last, W.M. (Eds.), Tracking Environmental Change Using Lake Sediments. Terrestrial, Algal, and Siliceous Indicators, vol. 3. Kluwer Academic Publishers, Dordrecht, pp. 99-119.

Vorren, K.-D., Elverland, E., Blaauw, M., Ravna, E.K., Jensen, C.A.H., 2009. Vegetation and climate c. 12 300-9000 cal. yr BP at Andøya, NW Norway. Boreas 38, 401-420.

Walker, M.D., Everett, K.R., Walker, D.A., Birkeland, P.W., 1996. Soil development as an indicator of relative pingo age, Northern Alaska, U.S.A. Arctic and Alpine Research 28, 352-362. 
Walker, D.A., Raynolds, M.K., Daniëls, F.J.A., Einarsson, E., Elvebakk, A., Gould, W.A., Katenin, A.E., Kholod, S.S., Markon, C.J. Melnikov, E.S., Moskalenko, N.G. Talbot, S.S., Yurtsev, B.A., Team, C.A.V.M., 2005. The circumpolar arctic vegetation map. Journal of Vegetation Science 16, 267-282.

Walter, K.M., Edwards, M.E., Grosse, G., Zimov, S.A., Chapin III, F.S., 2007. Thermokarst lakes as a source of atmospheric $\mathrm{CH}_{4}$ during the last deglaciation. Science 318, 633-636.

Wetterich, S., Kuzmina, S., Andreev, A.A., Kienast, F., Meyer, H., Schirrmeister, L., Kuznetsova, T., Sierralta, M., 2008. Palaeoenvironmental dynamics inferred from late Quaternary permafrost deposits on Kurungnakh Island, Lena Delta, Northeast Siberia, Russia. Quaternary Science Reviews 27, 1523-1540.

Wooller, M.J., Zazula, G.D., Blinnikov, M., Gaglioti, B.V., Bigelow, N.H., Sanborn, P. Kuzmina, S., La Farge, C., 2011. The detailed palaeoecology of a mid-Wisconsinan interstadial (ca. $3200014 \mathrm{C}$ a BP) vegetation surface from interior Alaska. Journal of Quaternary Science 26, 746-756.

Yurtsev, B.A., 1982. Relics of the xerophyte vegetation of Beringia in northeastern Asia. In: Hopkins, D.M., Matthews Jr., J.V., Schweger, C.E., Young, S.B. (Eds.), Paleoecology of Beringia. Academic Press, New York, pp. 157-177.

\section{Further reading}

Namiotko, T., Danielopol, D.L., Pichler, M., von Grafenstein, U., 2009. Occurrence of an Arctic ostracod species, Fabaeformiscandona harmsworthi (Scott, 1899) (Ostracoda, Candonidae) in late glacial sediments of Lake Mondsee (Austria). Crustaceana 82, 1209-1212. 